\title{
A HUMAN RIGHTS FRAMEWORK FOR DEBT RELIEF
}

\author{
CHRYSTIN ONDERSMA*
}

\begin{abstract}
This project begins to answer the question: How might human rights obligations and standards inform lawmaking around remedies for overindebted individuals? Recently, policymakers in Europe have articulated a desire to incorporate human rights principles in their responses to consumer over-indebtedness. However, there has been no comprehensive analysis of how human rights principles might inform the various responses to over-indebtedness. Further, policy makers outside Europe, including those in the United States, have not even begun to consider a human rights based response to over-indebtedness. This paper analyzes the human rights that are implicated in the responses to over-indebtedness and discusses how each right can be taken into account. In undertaking this analysis, I suggest that a human rights based evaluation of nations' responses to over-indebtedness must be contextualized in nations' background rules including 1) the available social safety net, 2) the nature of consumer credit contracts that default laws permit to exist, and 3) permissible collection methods. This project should be particularly useful for two groups: 1) those drafting or proposing legislation addressing consumer over-indebtedness who are members of countries that have undertaken specific human rights obligations and 2) lawmakers or policymakers who wish their proposed legislation to reflect cognizance of human rights principles even when not obligatory. In addition, this project also illustrates how human rights informed responses to overindebtedness differ from the status quo in the United States.
\end{abstract}

* Associate Professor of Law, Rutgers School of Law-Newark. Many thanks to Jean Braucher, Susan Block-Lieb, Jorge Contesse, Andrew Dawson, Aaron Fellmeth, Yuliya Guseva, Melissa Jacoby, Ted Janger, Jason Kilborn, Beth Stephens, Penny Venetis, participants in the Rutgers-Newark faculty colloquia, and my research assistant, Ernest Yazzetti. 


\section{TABLE OF CONTENTS}

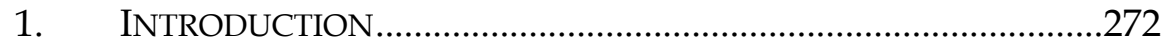

2. THE PROBLEM OF OVER-INDEBTEDNESS...................................278

2.1. The Rise of Over-Indebtedness .........................................278

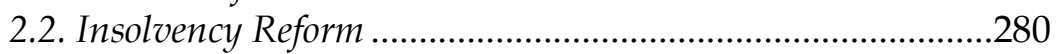

2.3. Budding Efforts to Consider Human Rights Principles in

Responding to Over-Indebtedness........................................281

3. OVERVIEW OF HUMAN RIGHTS

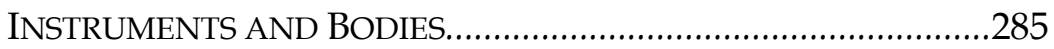

3.1. Human Rights and the United Nations ..............................288

3.1.1. Human Rights Instruments of the United Nations ....288

3.1.2. The United Nations and Human Rights Violations ...291

3.2. Human Rights and Regional International Bodies ...............291

3.2.1. The Inter-American System ...................................292

3.2.2. The European System ...............................................293

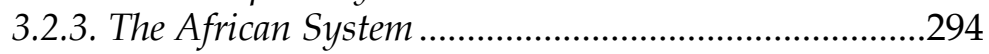

3.3. Domestic Legislation ............................................................294

4. HUMAN RIGHTS IMPLICATED IN ADDRESSING

OVER-INDEBTEDNESS ...................................................................295

4.1. Adequate Standard of Living..............................................296

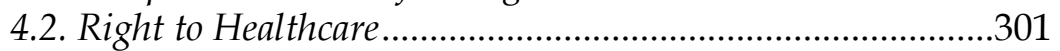

4.3. Right to Work and "Favorable" Remuneration ......................303

4.4. Prohibition on Incarceration for Failure to Pay Debt.............305

4.5. Prohibition of Debt Peonage ....................................................308

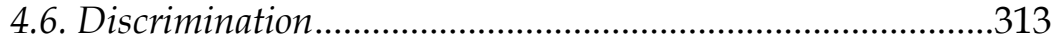

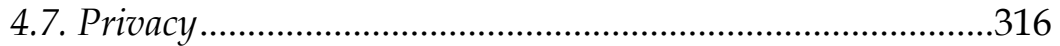

4.8. Human Dignity .................................................................319

5. CONSUMER BANKRUPTCY EXAMPLES: PROPERTY RIGHTS AND THE RIGHT TO DUE PROCESS..........................................322

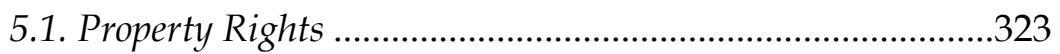

5.1.1. The Human Rights to Proprty Generally....................323

5.1.2. Creditors' and Debtors' Property Rights .....................326

5.1.3. Property Rights Complaint Insolvency Regimes .........331

5.2. The Right to Due Process .......................................................335

5.2.1. Due Process Rights as Human Rights Generally ........335

5.2.2. Debtors' and Creditors' Due Process Rights................336

5.2.3. Respecting Debtors' and Creditors' Due Process

Rights in Insolvency Regimes .........................................336 
6. INSIGHTS FOR POLICYMAKING

AROUND OVER-INDEBTEDNESS 338

6.1. Contextualizing the Evaluation of

Responses to Over-Indebtedness................................................339

6.1.1. Available Social Safety Net .......................................339

6.1.2. Limitations on Consumer Credtir Contracts ...............341

6.1.3. Default Collection Remedies.......................................341

6.2. Barriers and Alternatives to Insolvency Regimes ...................344

6.3. The "Effectiveness" of Responses to Over-Indebtedness ........345

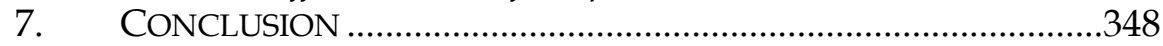




\section{INTRODUCTION}

As economies become ever more reliant on consumer credit fueled growth, nations have increasingly been required to decide whether and how to address the problem of household overindebtedness. The human and economic consequences of consumer over-indebtedness have been felt even more sharply since the global financial crisis and its aftermath. Consumer overindebtedness is both a broader economic problem and also a problem of human suffering. Individuals carrying heavy debt burdens often experience shame, marginalization, exclusion, and the inability to meet their basic needs. ${ }^{1}$ In addition, the processes for collecting debt exacerbate this suffering. In one incident in the United States, a son was unable to pay for his father's cremation, and the creditor's collection method was to leave the father's dead body on the son's front stoop with a sheet over it. ${ }^{2}$ In other cases, failure to pay debts can lead to imprisonment. ${ }^{3}$ Meanwhile, creditors also have valid concerns about losses stemming from debtors who are unable to pay, and the economy as a whole suffers because too many individuals have to devote their disposable income to servicing debt.

Although much of the response to the global financial crisis has been macroeconomic (bank safety and soundness, new rules for derivatives trading, and so forth), ${ }^{4}$ there has also been discussion

1 Insolvency and Creditor/Debtor Regimes Task Force, Report on the Treatment of the Insolvency of Natural Persons, WORLD BANK 1, 43 (Dec. 14, 2012) [hereinafter World Bank Report], http://wwwwds.worldbank.org/external/default/WDSContentServer/WDSP/IB/2013/05/0 2/000333037_20130502131241/Rendered/PDF/771700WP0WB0In00Box377289B0 OPUBLIC0.pdf.

2 Son Can't Pay, So Father's Body Is Returned, N.Y. TIMES (Oct. 14, 1992), http:/ / www.nytimes.com/1992/10/14/us/son-can-t-pay-so-father-s-body-isreturned.html.

3 Ethan Bronner, Poor Land in Jail as Companies Add Huge Fees for Probation, N.Y. TIMES (July 2, 2012), http://www.nytimes.com/2012/07/03/us/probationfees-multiply-as-companies-profit.html?smid=pl-share.

4 See, e.g., Yacine Aït-Sahalia, Jochen Andritzky, Andreas Jobst, Sylwia Nowak \& Natalia Tamirisa, Market Response to Policy Initiatives During the Global Financial Crisis, 87 J. INT'L ECON. 162 (2012), available at http://www.princeton.edu/ yacine/crisismarketresponse.pdf (assessing the impact of macroeconomic policy initiatives on the market during the financial crisis). See also Dodd-Frank Wall Street Reform and Consumer Protection Act, Pub. L. No. 111-203, 124 Stat. 1376 (2010) (delineating the Dodd-Frank laws passed after the financial crisis with the goal to support financial stability and protect 
of reform to consumer insolvency regimes; that is, the legal system for resolving consumer over-indebtedness. In the wake of the 2008 global financial crisis, which left individuals in many countries struggling to meet their consumer debt obligations - mortgage obligations in particular - several countries radically revised their consumer insolvency laws, and others are considering implementing a consumer insolvency regime for the first time. ${ }^{5}$ Furthermore, the World Bank issued a report reviewing the various insolvency regimes designed to address consumer overindebtedness. ${ }^{6}$

In both the U.S. and abroad, responses to over-indebtedness have historically not considered or incorporated human rights principles. Recently, however, European policymakers have expressed a desire to incorporate human rights principles into their approach to consumer over-indebtedness. Yet this aspiration has not so far been followed by a comprehensive analysis of what human rights are implicated in the response to over-indebtedness and how they are implicated. Only two scholars have analyzed the European human rights obligations for official insolvency systems, and they focused primarily on business insolvency. ${ }^{7}$ There has

consumers); M. Okan Tasar, Financial Regulations in the Process of Global Financial Crisis and Macroeconomics Impact of Basel III, 7 WORLD ACAD. SCI., ENG'G \& TECH. 601 (May 23, 2013), available at http://waset.org/publications/4063 (discussing Basel III, a global regulatory standard and its macroeconomic impacts); Jeremy Scott, The Faltering Financial Transaction Tax and the Future of Wall Street, FORBES (Sept. 19, 2013, 9:46 http://www.forbes.com/sites/taxanalysts/2013/09/19/the-faltering-financialtransaction-tax-and-the-future-of-wall-street/ (revisiting the Dodd-Frank Act and the Financial Transaction Tax and noting the failure of these efforts in reregulating the financial sector); Drew Singer, EU Official Makes Final Push on Financial Transaction Tax, LAw360 (Feb. 5, 2014, 4:37 PM), http://www.law360.com/articles/507218/eu-official-makes-final-push-on-

financial-transaction-tax (considering both sides of the debate on the Financial Transaction Tax - a minimum 0.1 percent tax on nonderivative transactions and a minimum 0.01 percent tax on derivative transactions).

5 Study on Means to Protect Consumers in Financial Difficulty: Personal Bankruptcy, Datio in Solutum of Mortgages, and Restrictions on Debt Collection Abusive Practices, LONDON ECON. 246-47 (Dec. 2012) [hereinafter London Economics Report], http://ec.europa.eu/internal_market/finservicesretail/docs/fsug/papers/debt_solutions_report_en.pdf.

6 See generally World Bank Report, supra note 1.

7 See Jan C. van Apeldoorn, Human Rights in Insolvency Proceedings, 12 L. Bus. \& FiN. (2012); George Kodek, The Impact of the European Convention of Human Rights and Fundamental Liberties on Insolvency Proceedings, in THE CHALLENGES OF INSOLVENCY LAW REFORM IN THE 21sT CENTURY 571-88 (Henry Peter, Nicolas Jeandin \& Jason Kilborn eds., 2006) (describing insolvency proceedings as 
been no human rights based analysis of the myriad issues pertaining to responses to consumer over-indebtedness that is contextualized in each nations' background rules regarding the creation of credit, debt collection, and social welfare policies. There also has been only limited recognition that creditors' human rights (such as rights to property and due process) may also be implicated in responses to over-indebtedness.

Thus, although a number of policymakers have acknowledged the need to consider human rights concerns, human rights concerns have not actually been incorporated into responses to consumer over-indebtedness. There is only limited guidance for lawmakers regarding how human rights concerns should be adequately accounted for in new laws targeted at treating overindebtedness.

In Europe, where policymakers have expressed a desire to consider human rights principles, there is only an incomplete discussion of human rights implications for over-indebtedness. Policymakers outside Europe are even further behind, as they have not even begun to consider how human rights principles might influence responses to over-indebtedness. The United States has long been thought to have the most liberal consumer bankruptcy regime, yet legal scholarship has yet to consider whether the U.S. response to over-indebtedness is consistent with human rights principles.

This paper seeks to fill these gaps. I identify the human rights obligations or standards that may be implicated in addressing consumer over-indebtedness. In undertaking this analysis, I suggest that a human rights based evaluation of nations' insolvency systems or lack thereof must be contextualized in nations' background rules including: 1) the available social safety net, 2) the nature of consumer credit contracts that default laws

\footnotetext{
a guide to practice, but also mentioning the impact on human rights, such as, inter alia, protection of property, the right to protect private and family life, and freedom of movement). Application of human rights principles to the resolution of insolvency has also been used in the foreign debt context. The Human Rights Council endorsed the Guiding Principles on Foreign Debt and Human Rights drafted by the United Nations High Commissioner for Human Rights. The Principles state that debt relief for overburdened debtor countries is to be considered in light of the human rights framework, including borrower states' human rights obligations. Guiding Principles on Foreign Debt and Human Rights, U.N. HUMAN RIGHTS, http://www.ohchr.org/en/Issues/Development/IEDebt/Pages/GuidingPrincip les.aspx (last visited Jan. 22, 2014).
} 
permit to exist, and 3) permissible collection methods. After discussing the human rights principles that may be implicated in nations' response to consumer over-indebtedness, I suggest that efforts at harmonizing responses to consumer over-indebtedness that strive to reflect human rights concerns should acknowledge that a one-size-fits-all approach may not be appropriate given the varied background rules and practices. I also suggest that if an insolvency regime is necessary to satisfy human rights concerns, the relief provided must be accessible and effective.

In addition to providing a guide for how to incorporate human rights principles into responses to over-indebtedness, this analysis also highlights the gaps that result from failing to consider human rights principles. In other words, responses to over-indebtedness that are fully cognizant of human rights principles would diverge from the status quo in many cases. Because my expertise is in U.S. consumer over-indebtedness, I focus primarily on U.S. examples. These examples suggest that current responses to overindebtedness in the U.S. do not fully comply with human rights principles. Although I focus on U.S. examples, my framework can be applied to laws around responses to over-indebtedness abroad.

The nature of the response to over-indebtedness that human rights principles require depends upon the nature of experience of indebtedness itself in any given context. This context includes both social norms and government policy. With respect to social norms, for individuals in some countries, indebtedness itself may carry severe social stigma and shame. For others, indebtedness itself may be acceptable, but declaration of bankruptcy or insolvency may be stigmatizing or shame-inducing. There are also significant policy variations. Consumer protection laws vary with respect to restrictions on the nature of the contract and also with respect to the collection methods permitted. Welfare policies also vary substantially; each government has made its own policy judgment regarding the degree to which taxpayers will subsidize food, education, healthcare, and housing. Finally, each jurisdiction provides varying degrees of default rights to creditors, particularly in determining when a contractual right of a secured creditor rises to a property right.

In spite of - and in light of - these variations, a human rights framework may be a useful tool for establishing baseline protections of both debtors and creditors in treating consumer over-indebtedness. Countries can choose among a variety of legislative options to ensure that the basic human rights of over- 
indebted individuals are not jeopardized. Some countries may focus on providing robust social safety nets that ensure that individuals can meet their basic needs for food and housing. Other countries may sharply circumscribe the debt collection methods available to creditors, for example, by restricting invasive collection practices and limiting the assets that can be seized or wages that can be garnished. In effect, these countries aim to protect debtors' rights to dignity, privacy, just remuneration, and freedom from discrimination. If background rules leave the debtor exposed to human rights violations, the nation state could comply with human rights principles by maintaining or creating an accessible insolvency regime that permits the debtor to opt out of the default rules. For example, initiation of consumer insolvency proceedings could trigger the immediate cessation of collection proceedings that would otherwise interfere with privacy rights, or insolvency proceedings could permit a discharge of debt such that the debtor retains sufficient income moving forward to meet the basic needs of herself or her dependents. Similarly, insolvency regimes can complement rather than interfere with creditors' human rights.

A few words about what this paper does not do. First, precisely because the human rights issues pertaining to the response to over-indebtedness will vary depending on the social and legal context, this discussion necessarily overlaps with broader concerns relating to over-indebtedness, including the regulation of financial institutions that participate in the consumer debt market. However, because regulation of business entities raises a host of additional issues - including whether and to what degree business entities themselves have human rights obligations - I have chosen to address separately the specific human rights concerns that arise at or prior to the time of contract creation. ${ }^{8}$ Second, this paper does not undertake the normative task of arguing that nations should approach consumer debt from a human rights standpoint - that work is done in a separate paper.

Instead, this paper addresses the reality that some countries and organizations have stated a desire to incorporate human rights principles in treating over-indebtedness - and yet this desire has not so far been accompanied by an analysis of the human rights principles implicated in addressing over-indebtedness. This paper

8 Chrystin Ondersma, A Human Rights Approach to Consumer Credit (unpublished manuscript) (on file with author). 
takes that step, offering a human rights framework for responding to over-indebtedness. This analysis will be useful for two groups: 1) those drafting or proposing legislation addressing consumer over-indebtedness who are members of countries that have undertaken specific human rights obligations, and 2) lawmakers or policymakers who wish their proposed legislation to reflect cognizance of human rights principles even when not obligatory. In addition, for countries like the United States that have not yet considered human rights principles in responding to overindebtedness, this paper illustrates some of the ways in which responses to over-indebtedness that reflect cognizance of human rights principles would differ from the status quo.

This paper proceeds as follows: Part 2 briefly discusses the problem of consumer over-indebtedness and the various responses for treating over-indebtedness that have emerged. Part 3 provides a brief overview of the human rights system so that the reader unfamiliar with the human rights regime will understand the circumstances under which the human rights standards and obligations discussed in subsequent parts can be implemented or enforced. In Part 4, I briefly review each human rights principle that could potentially be implicated in addressing consumer overindebtedness. In undertaking this application, I consider whether an insolvency regime could ameliorate the human rights concerns raised by application of the principle in question, whether an insolvency regime is necessary to address these human rights concerns, and what may be required for the insolvency regime itself to account for the human rights concerns. This analysis emphasizes that a human rights based approach to overindebtedness must be contextualized in a nation's background rules. Because the human rights discussed in Part 4 are primarily at issue for consumer debtors, the analysis is debtor focused. Part 5 undertakes a more detailed analysis of two specific human rights: the rights to property and due process rights. I focus on these rights separately because they implicate debtors and creditors to an equal degree and this analysis highlights the need to balance debtors' and creditors' rights. Part 6 summarizes the insights that emerge from this analysis; namely, efforts at harmonizing responses to consumer over-indebtedness that strive to reflect human rights concerns should acknowledge that a one-size-fits-all approach may not be appropriate given the varied background rules and practices. Part 7 concludes by offering some benefits of a human-rights-compliant response to over-indebtedness. 


\section{THE PROBLEM OF OVER-INDEBTEDNESS AND RESPONSES}

\subsection{The Rise of Over-Indebtedness}

Consumer over-indebtedness has rapidly arisen as a paramount concern in a number of countries. ${ }^{9}$ This paper implicates the broad array of responses to over-indebtedness in addition to the narrower and over-lapping issues of insolvency and bankruptcy. The Council of Europe considers over-indebtedness to cover "at least" those "situations where the debt burden of an individual or a family continuously and/or manifestly exceeds its payment capacity, resulting in systematic difficulties, and sometimes in failure, in paying the creditors." 10 The World Bank Report arrived at a similar definition of over-indebtedness, describing it as "the debtor's ongoing inability to service current obligations on all outstanding obligations as they become due."11 My discussion of the response to over-indebtedness is designed to cover the same territory as the World Bank Report's discussion of nations' "treatment of insolvency," which the Report calls "any system for alleviating the burdens of excessive debt and allocating benefits and losses, both among creditors and as between creditors and natural person debtors[.]"12

Over the past thirty years, household debt has risen exponentially among many developed and developing countries. ${ }^{13}$ Prior to 1975 , household debt seldom rose above $75 \%$ of annual income. By 2000, U.K. and U.S. household debt was equivalent to twelve months' income. ${ }^{14}$ The U.S. Federal Reserve reported an

9 See generally, e.g., INTERNATIONAL RESPONSES TO ISSUES OF CREDIT AND OvERINDEBTEDNESS IN THE WAKE OF CRISIS (Therese Wilson ed., 2013).

10 CouncIl of Europe, Recommendation CM/Rec(2007)8 of the Committee of Ministers to Member States on Legal Solutions to Debt Problems, If 16 [hereinafter Council of Europe Recommendation],

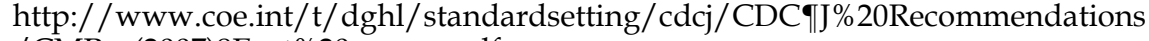
/CMRec(2007)8E_et\%20expose.pdf.

11 World Bank Report, supra note 1, ๆ 39.

12 Id. 17.

13 Tyler Durden, The Debt of Nations, Zero Hedge (June 4, 2013, 6:36 PM), http://www.zerohedge.com/news/2013-06-04/debt-nations.

14 Id. 
increase of credit card debt from $\$ 11$ billion in 1973 to $\$ 770.5$ billion in 2003 - about $\$ 6,950$ per household. ${ }^{15}$ Household debt burdens also increased exponentially in Russia (by a factor of 20 between 2000 and 2007); the average debt now amounts to over $\$ 15,000$, where the average annual income is only $\$ 7,500 .{ }^{16}$ Between 2007 and 2010, household debt increased 35\% in the Netherlands, $21 \%$ in Greece, and $18 \%$ in Hungary, Poland, and the Slovak Republic. ${ }^{17}$

In terms of total household debt, Denmark, Norway, and Switzerland have the highest household debt loads on average (above \$100,000 in 2012). Ireland and the Netherlands have close to $\$ 80,000$ in average household debt, while Canada, Sweden, the U.S., the U.K., and Singapore have between $\$ 40,000$ and $\$ 60,000$ in average household debt. This compares to lower levels in Spain $(\$ 31,200)$, Portugal $(\$ 25,800)$, Italy $(\$ 23,900)$, and Greece $(\$ 19,000) .18$

Given the nature of debt - if it cannot be timely serviced it grows quickly, and can grow exponentially if interest rates are high - over-indebtedness often entails a "downward spiral of growing indebtedness from which the debtor cannot escape without intervention[.]"19 The intervention may take the form of some kind of insolvency regime or other protection against debt enforcement. ${ }^{20}$ Common triggers of over-indebtedness include "unemployment, illness, divorce, or other income interruption or unexpected expense." 21 In the U.S., the housing crisis left many unable to meet their mortgage obligations. In addition, as bank losses infected the real economy, unemployment increased, leaving many families to rely on credit to fill the gap between income and expenses.22

\footnotetext{
15 Federal Reserve Bank, Federal Reserve Statistical Release, Consumer Credit Historical Data, Table G.19, available at www.federalreserve.gov/release/g19hist/cc_hist_r.txt.

16 Fear over Default as Personal Bank Debt in Russia Doubles in Two Years, Russia TODAY (last updated July 29, 2013, 1:23 PM), http://rt.com/business/russia-banks-people-debt-double-732/.

17 OECD (2012), National Accounts of OECD Countries, OECD Publishing, summary available at http://www.oecd-ilibrary.org/sites/factbook-2013en/03/03/02/index.html?itemId=/content/chapter/factbook-2013-28-en.

18 Durden, supra note 13.

19 World Bank Report, supra note 1, ๆ 39.

20 Durden, supra note 13.

21 Id.

22 Patricia McCoy, Barriers to Foreclosure Prevention During the Financial Crisis, 55 ArIZ. L. REV. 723, 728 (2013) (citing John Kiff \& Vladimir Klyuev, Staff Position Note, Foreclosure Mitigation Efforts in the United States: Approaches and
} 


\subsection{Insolvency Reform}

As the financial crisis and its associated debt woes infected countries around the globe, many countries without consumer insolvency regimes adopted or considered adopting consumer debt relief measures. ${ }^{23}$ Latvia, Slovenia, and Poland initiated individual discharge laws. ${ }^{24}$ Sweden radically reformed its bankruptcy laws to speed up relief and strictly limited repayment plans longer than five years. ${ }^{25}$ The Netherlands reformed their debt settlement procedures and allowed discharge of debt after one year rather than three and also allowed courts to force creditors to accept debtors' proposed out-of-court plans. The U.K. introduced debt relief orders. France introduced laws permitting immediate discharge over the dissent of creditors.26 Greece introduced personal discharge for consumers. ${ }^{27}$ Ireland and Germany both reformed its bankruptcy laws to permit discharge after three years of plan repayment. ${ }^{28}$ Austria also proposed personal bankruptcy reform. ${ }^{29}$ Italy introduced consumer bankruptcy procedures permitting a discharge after a four-year repayment period. ${ }^{30}$

Challenges, INT'L Monetary Fund, STAFF Position Note (SPN/09/02, 2009), at 4-5 (2009), http://www.imf.org/external/pubs/ft/spn/2009/spn0902.pdf. Adjustable-rate mortgages (ARMs) that were particularly troubling were $2 / 28$ or 3/27 ARMs, interest-only ARMs, and option payment ARMs. Id. "By early 2012, U.S. housing prices had fallen 33\% since their 2006 high, wiping out about $\$ 7$ trillion in household equity. It was the nation's most severe housing price decline since the Great Depression." Id. at 729 (citing BD. OF GOVERNORS OF THE FED. Reserve Sys., The U.S. Housing MARKet: CuRrent CONDITIONS AND Policy CONSIDERATIONS 3 (2012)).

23 London Economics Report, supra note 5, at 7.

24 Id. at 246.

25 Id.

26 Id.

27 Nomos (2007:3588) [Insolvency Code], 2007 (Greece); Fek [Page of the Paper of the Government], 2007, A/10.7.2007, amended by Nomos (2012:4072) [Improvement of the Corporate Environment - New Corporate Form Trademarks - Real Estate - Regulation of Issues Relating to Shipping, Ports, Fishing and Other Provisions], 2012 (Greece).

28 London Economics Report, supra note 5, at 247.

29 Id.

30 Legge 27 gennaio 2012, n. 3, in G.U., Jan. 30, 2012, n. 24 (It.) [Law of Jan. 27, 2012, no. 3], Disposizioni in Materia di Usura e di Estorsione, Nonche' di Composizione delle Crisi da Sovraindebitamento) [Regulation on Usury and Extortion, as well as on Settlement of Overindebtedness Crises]. 
Colombia introduced discharge proceedings in 2012.31 Although Russia has not yet adopted a consumer insolvency regime, alarm over growing consumer over-indebtedness has prompted discussion about reforms. ${ }^{32}$

The U.S. considered but rejected changes to its bankruptcy laws that would have permitted mortgages to be modified in bankruptcy. In spite of the proposed amendment's defeat, some bankruptcy courts are aiding the modification of mortgages in bankruptcy through loss mitigation programs. ${ }^{33}$ A number of state and federal programs also attempted to provide opportunities for mortgage modification, but unfortunately, the programs have saved far fewer homes than anticipated. ${ }^{34}$

\subsection{Budding Efforts to Consider Human Rights Principles in Responding to Over-Indebtedness}

In the past decade, the problem of over-indebtedness has begun to be recognized as a human rights concern in Europe. Even before the financial crisis, the Committee of Ministers of the Council of Europe, which is charged with implementing the European Convention on Human Rights (ECHR), issued a report discussing the human rights implications for consumer overindebtedness and proposing possibilities for harmonizing responses to over-indebtedness. ${ }^{35}$ The Recommendation concluded that "over-indebtedness [in addition to poverty and consumer insolvency ${ }^{36}$ may lead to social and health problems

31 Código General Del Proceso [Code of Civil Procedure], art. 571(1).

32 Russia TODAY, supra note 17.

33 Tara Siegel Bernard, Losing Homes in the Wait for a Rescue, N.Y. TIMES, May 14, 2009, at B1; see also generally Adam Levitin, Resolving the Foreclosure Crisis: Modification of Home Mortgages in Bankruptcy, 2009 Wisconsin L. Rev. 565, 565-640 (2009); Hon. Cecilia Morris \& Mary K. Guccion, The Loss Mitigation Program Procedures for the United States Bankruptcy Court for the Southern District of New York, 19 AM. BANKR. INST. L. REV. 1, 2 (2011).

34 See, e.g., Jean Braucher, Humpty Dumpty and the Foreclosure Crisis: Lessons from the Lackluster First Year of the Home Affordable Modification Program (HAMP), 52. ARIZ. L. REV. 727, 744-68 (2010) (examining the disappointing results of the HAMP program in terms of the low numbers of struggling homeowners whose homes were saved).

35 Council of Europe Recommendation, supra note 10.

36 When I use the term "insolvency," I include not only balance sheet insolvency but also the inability to service one's debt obligations as they come 
and exclusion of individuals and families from society[.]"37 The Recommendation did not, however, discuss the myriad of human rights that are implicated in addressing consumer overindebtedness. In fact, the only human right specifically mentioned in the report was human dignity. Similarly, while the World Bank Report on the treatment of consumer over-indebtedness acknowledged in a passing sentence that there may be human rights implications for insolvency regimes, the Report does not offer specific guidance on the human rights standards or obligations that are implicated in addressing over-indebtedness. ${ }^{38}$ Finally, the Financial Services User Group published a policy report recommending that each EU member country have a consumer insolvency regime, and that "recognised fundamental rights and the dignity of human beings should be at the core of any insolvency/restructuring regime." 39 However, the policy report failed to identify the human rights at issue or discuss what would be necessary for a consumer insolvency regime to comply with human rights.

The European Ministers of Justice of the Council of Europe, who are responsible for implementing the European Convention on Human Rights, ${ }^{40}$ met in 2005 for their 26th conference to discuss legal solutions to over-indebtedness consistent with human rights principles. ${ }^{41}$ They adopted a Resolution (Resolution No. 1 on

due. Balance sheet insolvency is both under and over-inclusive. Many individuals are insolvent (for example, new home owners and college graduates with hefty student loan debt) but are capable of servicing their debt and meeting their basic needs. Some individuals have modest assets (a home, perhaps) but have a liquidity crisis: an elderly individual with fixed income and medical debt, for example. Such an individual may be over-indebted and their human rights may be at risk even if the value of their home exceeds their medical liabilities.

37 Council of Europe Recommendation, supra note 10, 917.

38 See generally World Bank Report, supra note 1.

39 Study on Means to Protect Consumers in Financial Difficulty: Personal Bankruptcy, Datio in Solutum of Mortgages, and Restrictions on Debt Collection Abusive Practices, FIN. SERVS. USER GROUP, at http:/ /ec.europa.eu/internal_market/finservicesretail/docs/fsug/papers/debt_solutions_research_study_position_en.pdf (last visited Jan. 22, 2014).

40 Jason J. Kilborn, EXPERT Recommendations and the EVOlution of EUROPEAN BEST PRACTICES FOR THE TREATMENT OF OVERINDEBTEDNESS, 1984-2010, 11 L. BUS. \& FIN. 10 (2011).

41 26th Conference of European Ministers of Justice, Resolution No. 1 on Seeking Legal Solutions to Debt Problems in a Credit Society at the 26th Conference of European Ministers of Justice, COUNCIL OF EuROPE (Helsinki Apr. 7 8, 2005) [hereinafter Helsinki Resolution], 
Seeking Legal Solutions to Debt Problems in a Credit Society $)^{42}$ addressing the issue of over-indebtedness. ${ }^{43}$ The Committee of Ministers emphasized the need to address over-indebtedness in light of human rights obligations ${ }^{44}$ and tasked the European Committee on Legal Cooperation (CDCJ) with "prepar[ing] an appropriate instrument defining legislative and administrative measures, and proposing practical remedies." 45 The CDCJ responded by drafting a report entitled "[1]egal solutions to debt problems" 46 which the Committee of Ministers then adopted. The Recommendation describes the problem of over-indebtedness as a situation that "frequently leads to social and health problems and social exclusion of families and may put children's basic needs at risk." 47 In its recommendation pertaining to debt recovery, the CDCJ emphasized the need to "respect[] the debtor's rights and human dignity at all stages of debt collection and debt enforcement procedures without infringing on the rights of creditors[.]" 48 The scope of debt collection is also limited by the requirement that the debtor retain "essential assets" as well as "basic living needs of the debtor and his/her family[.]" 49 Furthermore, the CDCJ issued recommendations pertaining to the rehabilitation of the debtor, emphasizing that repayment plans should be "reasonable" 50 and that discharge should be available where "other measures have proved to be ineffective" and "with a view to providing ... . [debtors] a new opportunity for engaging in economic and social activities[.]" 51

The Council of Europe prepared a document responding to the report with specific areas for government action. ${ }^{52}$ The action areas

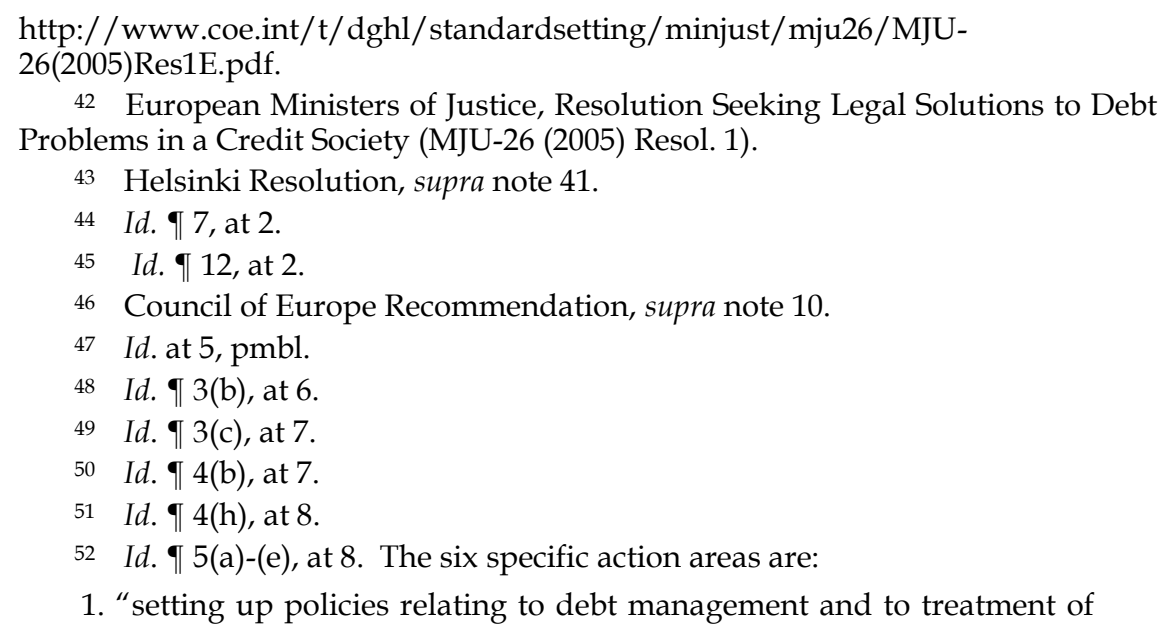


include establishing policies for debt management and the responses to the over-indebted, ensuring "the quality of all services related to over-indebtedness and the impartiality of providers," 53 encouraging participation of lenders, and establishing "easy access to information about consumer rights" and financial management awareness. ${ }^{54}$ The Council of Europe also responded with specific solutions for the prevention of over-indebtedness, ${ }^{55}$ alleviation of the effects of over-indebtedness, ${ }^{56}$ and rehabilitation of the overindebted. ${ }^{57}$ The Council specifically addressed the need to respect the debtor's "human dignity" in the debt collection process, ${ }^{58}$ and focused on the need to encourage the financial and social inclusion of over-indebted individuals. ${ }^{59}$

over-indebted individuals and families and ensuring uniformity of such policies," 2. "ensuring effective co-operation between the competent bodies and the professionals involved ... ," 3. "setting up debt advice, counselling and mediation mechanisms, as well as ensuring, or at least encouraging, effective participation of lending institutions . . . in implementing national policies for debt management; d. ensuring appropriate quality [] and impartiality of [] services ... [related to overindebtedness]," 4. "providing easy access to information about consumer rights and . . [promoting awareness in relation to financial management]."

53 Council of Europe Recommendation, supra note 10, ๆ 42, at 19.

$54 \quad I d .95(\mathrm{e})$, at 8.

55 Id. ๆ 2(a)-(e), at 6. Prevention:

1. "collecting information and statistics on debt problems and analysing the situation," 2. "introducing . . . financial literacy . . . and budget management ... [ [in] national education system," 3. "effective access to impartial financial, social and legal advice and counseling," 4. "providing the necessary measures and regulations to ensure responsible practices during all phases of the credit relationship," 5. "safeguarding the rights of the guarantors to information."

Id.

56 Id. ๆ 3(a)-(e), at 6-7. Alleviation of effects:

1. "ensuring an efficient ... enforcement system as well as appropriate legislation," 2. "respecting the debtor's rights and human dignity . . . [in] debt enforcement procedures," 3. "introducing enforcement alleviation procedures, including the protection of the essential assets of the debtor," 4. "ensuring the rights of the guarantors . . . at all stages of debt enforcement procedure," 5. "recognition and enforcement ... of payment judgments and repayment plans."

Id.
$57 \quad$ Id. ๆ 4(a)-(h), at 7-8.
$58 \quad$ Id. $93(\mathrm{~b})$, at 6.
59 Id. ๆ 4(a)-(h), at 7-8. Rehabilitation: 
In spite of the mandate to consider the human rights implications of over-indebtedness, the Council did not undertake any further analysis regarding which human rights obligations or standards might be implicated in addressing over-indebtedness. The Report and Recommendations seem to be focused around the treatment of over-indebtedness as a human dignity concern. The Report does acknowledge that over-indebtedness can interfere with the ability of debtors to meet basic needs, but these concerns are considered in passing rather than analyzed. In other words, the Report does not undertake the task of suggesting what specific changes may be necessitated by human rights principles. In addition, concerns involving discrimination, equality, and property are absent. Outside of Europe, including in the United States, human rights concerns have been absent from discussions around solutions for consumer over-indebtedness.

\section{OVERVIEW OF HUMAN RIGHTS INSTRUMENTS AND BODIES}

This Part undertakes two objectives. First, it provides a brief overview of the human rights instruments that encapsulate the human rights standards pursuant to which I will consider the efforts to address situations of over-indebtedness. Second, it provides a brief overview of human rights bodies that have the capacity to enforce human rights obligations; in other words, it begins to show how some nations can be held accountable for human rights violations. I discuss the functions and instruments of the United Nations and of the regional human rights bodies, and I acknowledge that domestic legislation can also address human rights. This framework is essential to understanding the analysis that follows, in which I apply these human rights standards to the responses to over-indebtedness. This Part will be amply familiar to

1. "ensuring that debtors have effective access to impartial advice and to debt adjustment [procedures], 2. "ensuring that debt adjustment covers all debts," 3. "establishing . . . extra-judicial settlements . . . between the debtor and creditor," 4. "limiting the means of creditors to hinder debt settlements unreasonably," 5. "encouraging [] financial and social inclusion of over-indebted individuals," 6. "encouraging [] active participation of the debtor in debt settlement, 7. "allowing partial or total discharge of the debts of individuals and ... families."

Id. 
those working and writing in the human rights field; human rights scholars and practitioners should skip this Part and begin reading Part 5.

By "human rights obligations" I refer to the minimum human rights obligations that a nation or other state actor is bound to provide by force of law. Human rights obligations vary substantially from country to country and even from city to city. In the United States, for example, some states and municipalities have adopted human rights obligations beyond what the United States is obliged to guarantee by treaty. ${ }^{60}$ Redress and enforcement mechanisms also vary substantially; some nations may have agreed to abide by human rights obligations in principle but have not agreed to be subject to review or enforcement actions, whereas others have given human rights instruments the force of national law and/or have agreed to be subject to review by an international human rights body. ${ }^{61}$

By "human rights standards," in contrast to "human rights obligations," I refer to the human rights that most nations have acknowledged and aspire to protect, even where an enforcement mechanism is lacking. Recognized rights include those human rights described in the International Covenant on Civil and Political Rights (ICCPR) and the International Covenant on Economic, Social, and Cultural Rights (ICESCR), both of which are treaties. The Universal Declaration of Human Rights, which preceded these treaties, also sets forth a number of commonly accepted human rights, many of which were later incorporated into the ICCPR and ICESCR. The human rights instruments adopted by regional bodies that have undertaken human rights obligations reflect many of the same standards enshrined in these documents.

Not every human rights standard gives rise to a remedy in the event of violation. Although most countries accept the human rights described in the International Bill of Human Rights, redress is not available for every human rights violation. ${ }^{62}$ Redress is

60 See, e.g., Maine Human Rights Act, Me. Rev. StAt. AnN. Tit. 5, §§ 4551-634 (2013) (defining "disability" in 5 M.R.S.A. $\S 4553(7-A)$ in a wider sense than the definition provided by the Americans with Disabilities Act).

61 Human Rights Act 1998, c. 42 (1998) (U.K.).

62

Where not already provided for by existing legislative or other measures, each State Party to the present Covenant undertakes to take the necessary steps, in accordance with its constitutional processes and with the 
available only if the country accused of the violation has agreed to be held accountable by an international or regional human rights body, or if the right is protected by domestic law. Moreover, national law is the primary mechanism for protection of human rights, and human rights can be protected in national law without such legislation being explicitly labeled as pertaining to human rights. For example, many constitutions protect rights identified as human rights, including privacy, free speech, freedom from slavery, and freedom from discrimination.

Typically international human rights remedies will not be available until victims of human rights abuses have exhausted available national remedies. ${ }^{63}$ Additionally, human rights bodies violations are typically only redressable if state action perpetrates the violation. Although there is a movement toward the recognition of states' "positive obligations" to prevent private actors from violating human rights, most enforcement mechanisms are addressed at violations of states' "negative obligations" to refrain from interfering with human rights. ${ }^{64}$ Note, however, that whenever the state lends the force of its legal apparatus to private actors (such as debt collectors), state action is at work. Further, even when no enforcement mechanism compels positive obligations, nation states concerned about the human rights issues

provisions of the present Covenant, to adopt such laws or other measures as may be necessary to give effect to the rights recognized in the present Covenant.

International Covenant on Civil and Political Rights, Dec. 16, 1966, 999 U.N.T.S. 171, art. 2(2) [hereinafter ICCPR], available at http://www.ihumanrights.ph/wpcontent/uploads/2011/11/ccpr1.pdf.

63 Magdalena Sepúlveda Carmona, Int'l Council on Hum. Rts. Pol'y, CORRUPTION AND HuMAN RigHTS: MAKING THE CONNECTION 11 (Robert Archer ed., 2009), http://www.ichrp.org/files/reports/40/131_web.pdf; OFF. OF THE U.N. HigH COMM'r FOR Hum. RTs. (OHCHR), 23 Frequently Asked Questions About Treaty Body Complaints Procedures [hereinafter OHCHR Frequently Asked Questions], http://www.ohchr.org/Documents/HRBodies/TB/23FAQ.pdf (last visited Jan. 24, 2014); OFF. OF THE U.N. HigH COMM'R FOR Hum. RTs. (OHCHR), Human Rights Treaty Bodies - Individual Communications, http:/ / www.ohchr.org/EN/HRBodies/TBPetitions/Pages/IndividualCommuni cations.aspx (last visited Jan. 24, 2014).

64 Jean François Akandji-Kombe, Council of Europe, Positive Obligations Under the European Convention on Human Rights, 7 Hum. RTs. HANDBOOKS 1, 10 (2007) (explaining the difference between positive and negative obligations); see generally Dinah Shelton and Ariel Gould, Positive and Negative Obligations, in THE OXFORD HANDBOOK OF INTERNATIONAL HuMAN Rights LAW 562 (Dina Shelton ed., 2013). 
raised here may wish to voluntarily adhere to human rights standards.

I use the term "human rights principles" to include both human rights obligations and human rights standards; that is, I discuss adherence to human rights principles with the recognition that failure to consider the principle will not, in many cases, be a redressable human rights violation. Thus, while this section gives a sense of which human rights standards are accompanied by human rights obligations, my analysis that follows is not an analysis of what human rights law requires but rather asks what adherence to the human rights standard would look like, even if failure to satisfy this standard would not be penalized.

This manner of considering human rights - as principles worth following even absent a legal consequence for failure to follow them - carries some challenges. In order to decide what conduct human rights principles urge, it may be necessary to elucidate the content of each principle. But it makes little sense to attempt to do so without considering any of the case law interpreting the principles. On the other hand, the case law will vary and perhaps conflict from jurisdiction to jurisdiction, and it would be impossible, in the confines of this paper, to fully explore all human rights case law everywhere. Hence, I try here to draw upon case law in a limited manner; that is, I mention cases where useful to shed light on the content of a human rights principle in circumstances particularly relevant to the context of nations' responses to over-indebtedness. ${ }^{65}$

\subsection{Human Rights and the United Nations}

\subsubsection{Human Rights Instruments of the United Nations}

The Universal Declaration of Human Rights, which the U.N. General Assembly adopted in 1948, recognizes civil and political

65 There is one resource available that discusses the human rights obligations under the European Convention that arise in insolvency cases. See generally APELDOORN, supra note 7. The book's discussion is limited to the European Convention and is also limited to obligations related to insolvency regimes, not overall methods for addressing over-indebtedness. Id. 
rights as well as the "economic, social and cultural rights" that are "indispensable" for "dignity and the free development of [] personality." 66 The Declaration of Human Rights is not a treaty and does not give rise to enforcement mechanisms, but it is referenced in the preamble to treaties subsequently enacted and is sometimes considered part of "customary" international law. ${ }^{67}$ In addition, the 1968 United Nations International Conference on Human Rights stated that the Declaration "constitutes an obligation for the members of the international community."68 In setting forth economic rights, the Declaration affirms the right to "just and favorable remuneration" that ensures "for [each person] and [his or her] family an existence worthy of human dignity, and supplemented, if necessary, by other means of social protection" for each individual and his or her family. ${ }^{69}$ In addition, it affirms the right to rest and leisure, 70 and the right to "a standard of living adequate for the health and well-being of [each person and his or her] family, including food, clothing, housing and medical care ... .$" 71$

That said, many (if not most) of the rights espoused in the Declaration are not accompanied with any remedy in the event of violation, and some do not consider "human dignity" to be a human right. However, that does not mean that policymakers will not want their responses to over-indebtedness to reflect the human rights concerns raised in the Declaration. Indeed, in its short Recommendation, the Council of Europe focused primarily on the need for responses to over-indebtedness to respect human

66 Universal Declaration of Human Rights, G.A. Res. 217A, U.N. GAOR, 3d Sess., 1st plen. Mtg., U.N. Doc. A/810, art. 22 (Dec. 10, 1948), available at http://www.un.org/en/documents/udhr/.

67 Whether the UDHR forms part of customary international law is a subject of much debate. See generally ANTHONY A. D'AMATO, INTERNATIONAL LAW: Process AND Prospect 123-47 (1986); Myers S. McDougal, Harold D. LASSWEll \& Lung-Chu Chen, Human Rights and World Public Order: The Basic Policies of AN INTERNATIONAL LAW OF HuMAN DigniTy 273-74, 325-27 (1977); J.P. Humphrey, The Universal Declaration of Human Rights: Its History, Impact and Juridical Character, in Human Rights: THIRTY YeARS AFTER the UniVERSAl DeClaration 21, 37 (Bertram G. Ramcharan ed., 1979); Louis B. Sohn, The Human Rights Law of the Charter, 12 TeX. INT'L L.J. 129, 133 (1977).

68 Proclamation of Teheran, Final Act of the International Conference on Human Rights, U.N. Doc. A/Conf.32/41 (May 13, 1968), available at http://www1.umn.edu/humanrts/instree/12ptichr.htm.

69 Universal Declaration of Human Rights, supra note 66, art. 23.

70 Id. art. 24.

71 Id. art. 25. 
dignity. 72

The International Covenant on Civil and Political Rights, adopted by the U.N. General Assembly in 1966, commits its parties to protecting individuals' civil and political rights, including rights to life, ${ }^{73}$ freedom of religion, ${ }^{74}$ expression, ${ }^{75}$ and assembly. ${ }^{76}$ It also includes the right to privacy, ${ }^{77}$ freedom from discrimination ${ }^{78}$ and freedom from involuntary servitude or forced labor. ${ }^{79}$ The ICCPR has 167 parties, including the U.S. 80

The International Covenant on Economic, Social, and Cultural Rights, also adopted by the U.N. General Assembly in 1996, commits its parties to endeavor to provide their residents with positive economic, social, and cultural rights, including education, health, and an adequate standard of living, which includes food, clothing, and housing. ${ }^{81}$ The ICESCR has 160 parties. ${ }^{82}$ The U.S. and six other countries have signed but not ratified the ICESCR. The ICESCR, in contrast to the ICCPR, does not guarantee the rights it declares, but rather promises to achieve "progressive realization" of these rights, ${ }^{83}$ which at the very least includes the obligation not to impede realization of these rights. ${ }^{84}$

72 Council of Europe Recommendation, supra note 10.

73 Universal Declaration of Human Rights, supra note 66, art. 6.

74 Id. art. 18.

75 Id. art. 19.

76 Id. art. 21.

77 ICCPR, supra note 62. The U.S. signed the ICCPR in 1977 and ratified it in 1992. Id.

78 Id. art. 26.

$79 I d$. art. $8, \S 2$.

80 ICCPR, supra note 62. The U.S. signed the ICCPR in 1977 and ratified it in 1992.

81 International Covenant on Economic, Social and Cultural Rights, Dec. 16, 1966, 993 U.N.T.S. 3 [hereinafter ICESCR], available at http://www.ohchr.org/EN/ProfessionalInterest/Pages/CESCR.aspx.

82 Id.

83 Id. art. 2.1 (parties are obliged to "take steps ... to the maximum of its available resources, with a view to achieving progressively the full realization of the rights recognized in the present Covenant by all appropriate means, including particularly the adoption of legislative measures.").

84 U.N. Comm. on Econ., Soc. \& Cultural Rts., 5th Sess., General Comment 3: The Nature of States Parties' Obligations, U.N. Doc. E/1991/23 (1990), I 9 [hereinafter UN Comm. on Econ., Soc. \& Cultural Rts.], available at http://tbinternet.ohchr.org/_layouts/treatybodyexternal/Download.aspx?symb 


\subsubsection{The United Nations and Human Rights Violations}

United Nations bodies are responsible for addressing violations of the ICCPR and ICESCR. All parties to the ICCPR submit to monitoring by the United Nations Human Rights Committee. ${ }^{85}$ Redress for human rights violations under the ICCPR is available only pursuant to the First Optional Protocol.86 The First Optional Protocol to the ICCPR permits individuals to complain directly to the U.N. Human Rights Committee about violations of rights provided for in the ICCPR. A total of 114 nations are party to the Optional Protocol - the U.S. is not one of them. ${ }^{87}$

The Committee on Economic, Social, and Cultural Rights recognizes that immediate guarantee of each of the rights enshrined in the ICESCR may not be feasible; parties nevertheless must "take steps" toward realizing the rights, and must provide "minimum essential levels" of each of the rights. ${ }^{88}$ Pursuant to the Optional Protocol to the ICESCR, the Committee on Economic Social and Cultural Rights can consider complaints from individuals, but only those individuals from the ten countries who have ratified the Optional Protocol to the ICESCR. ${ }^{89}$

\subsection{Human Rights and Regional International Bodies}

In addition to the human rights enshrined in the United Nation instruments, several regional international bodies have made human rights commitments. The Organization of American States (OAS), members of the European Union, and members of the African Union each have accepted human rights obligations.

olno=INT\%2fCESCR\%2fGEC\%2f4758\&Lang=en (last visited Jan. 24, 2014) (“[D]eliberately retrogressive" measures are prohibited).

85 ICCPR, supra note 62.

86 OHCHR Frequently Asked Questions, supra note 63.

87 Optional Protocol to the International Covenant on Civil and Political Rights, 999 U.N.T.S. 171 (entered into force Mar. 23, 1976), available at https://treaties.un.org/Pages/ViewDetails.aspx?mtdsg_no=IV-

$5 \&$ chapter $=4 \&$ lang $=\mathrm{en}$.

88 UN Comm. on Econ., Soc. \& Cultural Rts., supra note 84, ๆ 8 8-9.

89 Optional Protocol to the International Covenant on Civil and Political Rights, supra note 87. The International Labor Organization also forms part of the United Nations and addressed concerns pertaining to workers' rights. 


\subsubsection{The Inter-American System}

The American Declaration of the Rights and Duties of Man (American Declaration) applies to members of the Organization of American States (OAS). ${ }^{90}$ The American Declaration was signed in 1948, and includes civil and political rights as well as economic, social and cultural rights, including property, work, leisure, and social security. ${ }^{91}$ The rights can be limited by the "just demands of the general welfare and the advancement of democracy."92 The American Convention on Human Rights (ACHR) was adopted in 1969 - by some members of the OAS, excluding the United States and enshrines in more detail civil and political rights including the right to humane treatment, 93 freedom from slavery, ${ }^{94}$ right to liberty, ${ }^{95}$ right to privacy, ${ }^{96}$ and the right to property. ${ }^{97}$ Parties also agree to "adopt measures... with a view to achieving progressively, by legislation or other appropriate means, the full realization of the rights implicit in the economic, social, educational, scientific, and cultural standards set forth in the Charter of the Organization of American States . . . "98 The InterAmerican Commission on Human Rights provides

90 The following 21 nations initially signed the OAS Charter in 1948: Argentina, Bolivia, Brazil, Chile, Colombia, Costa Rica, Cuba, Dominican Republic, Ecuador, El Salvador, Guatemala, Haiti, Honduras, Mexico, Nicaragua, Panama, Paraguay, Peru, United States of America, Uruguay, and Venezuela. The following 14 nations joined subsequently: Barbados, Trinidad and Tobago (1967); Jamaica (1969); Grenada (1975); Suriname (1977); Dominica (Commonwealth of), Saint Lucia (1979); Antigua, Barbuda, Saint Vincent, and the Grenadines (1981); the Bahamas (Commonwealth of) (1982); St. Kitts and Nevis (1984); Canada (1990); Belize and Guyana (1991). Who We Are, ORG. OF AM. STATES, http://www.oas.org/en/about/member_states.asp (last visited Jan. 24, 2014).

91 Org. of Am. States, American Declaration of the Rights and Duties of Man, May 2, 1948, OAS Doc. OEA/Ser.L.V/II.82 doc.6 rev.1, art. 1-28, at 17 [hereinafter American Declaration], available at http:/ / www.cidh.oas.org/Basicos/English/Basic2.american\%20Declaration.htm.

92 Id. art. 28.

93 Org. of Am. States, American Convention on Human Rights "Pact of San Jose, Costa Rica," art. 5, http://www.oas.org/dil/treaties_B32_American_Convention_on_Human_Rights.htm (last visited Jan. 24, 2014) [hereinafter American Convention].
94 Id. art. 6.
$95 \quad I d$. art. 7.
96 Id. art. 11.
97 Id. art. 21.
98 Id. art. 26. 
recommendations in response to petitions alleging human rights abuses by an OAS member. Petitions are typically limited to widespread human rights violations. ${ }^{99}$

\subsubsection{The European System}

All Council of Europe member states are bound by the European Convention on Human Rights (ECHR). ${ }^{100}$ The ECHR protects civil and political rights 101 such as life, ${ }^{102}$ liberty, ${ }^{103}$ fair trial, 104 and privacy, 105 freedom from servitude, ${ }^{106}$ and freedom from discrimination. ${ }^{107}$ The ECHR also provides for a right to property ${ }^{108}$ and a right to education. ${ }^{109}$ The European Court of Human Rights is responsible for adjudicating alleged violations of the ECHR, and individuals, organizations, or contracting nations (on behalf of their citizens) may bring claims to the European

99 Inter-American Commission on Human Rights, The Inter-American Human Rights System, HuM. RTS. EDUC. Assocs., www.hrea.org/index.php?doc_id=413 (last visited Jan. 24, 2014).

100 The member states include: Albania, Andorra, Armenia, Austria, Azerbaijan, Belgium, Bosnia and Herzegovina, Bulgaria, Croatia, Cyprus, Czech Republic, Denmark, Estonia, Finland, France, Georgia, Germany, Greece, Hungary, Iceland, Ireland, Italy, Latvia, Liechtenstein, Lithuania, Luxembourg, Malta, Republic of Moldova, Monaco, Montenegro, Netherlands, Norway, Poland, Portugal, Romania, Russian Federation, San Marino, Serbia, Slovak Republic, Slovenia, Spain, Sweden, Switzerland, 'The former Yugoslav Republic of Macedonia,' Turkey, Ukraine, United Kingdom. See COUNCIL OF Europe, http://www.coe.int/en/web/about-us/our-member-states (last visited Jan. 24, 2014).

101 Council of Europe, Convention for the Protection of Human Rights and Fundamental Freedoms, arts. 1-18, Sept. 3, 1953, E.T.S. 5, available at http://conventions.coe.int/Treaty/en/Treaties/Html/005.htm (last visited Jan. $24,2014)$.

102 Id. art. 2.

103 Id. art. 5.

104 Id. art. 6.

105 Id. art. 8.

106 Id. art. 4.

107 Id. art. 14.

108 Id. at Protocol 1, art. 1.

109 Id. at Protocol 1, art. 2; see also Parliamentary Assembly, Council of Eur., Resolution 1031 (1994) on the Honoring of Commitments Entered into by Member States When Joining the Council of Europe (1994), available at http://assembly.coe.int/Main.asp?link=/Documents / AdoptedText/ta94/ERES1 031.htm (last visited Jan. 24, 2014). 


\section{Court of Human Rights. 110}

\subsubsection{The African System}

All members of the African Union except South Sudan have ratified and are bound by the African Charter on Human and People's Rights (ACHPR). ${ }^{111}$ The ACHPR includes the rights such as freedom from discrimination, ${ }^{112}$ life, ${ }^{113}$ dignity, ${ }^{114}$ freedom from slavery, ${ }^{115}$ rights to due process concerning arrest and detention, ${ }^{116}$ the right to a fair trial,117 freedom of expression, 118 and the right to property. ${ }^{119}$ The African Commission on Human and Peoples' Rights has the responsibility of overseeing and interpreting the ACHPR. ${ }^{120}$

\subsection{Domestic Legislation}

Several nations, including South Africa, ${ }^{121}$ India, ${ }^{122}$ Belgium,

\footnotetext{
110 Eur. CT. of Hum. RTs., Council of Eur., Practical Guide ON ADMISSIBILITY CRITERIA (2011), available at http://www.echr.coe.int/Documents/Admissibility_guide_ENG.pdf (last visited Jan. 24, 2014).

111 State Reporting, AfricAN COMM'N ON Hum. \& PeOples' RTs., http://www.achpr.org/states/ (listing states that have ratified the ACHPR).

112 African Comm'n on Hum. \& Peoples' Rts., African (Banjul) Charter on Human and Peoples' Rights, art. 18, Oct. 21, 1986, OAU Doc. CAB/LEG/67/3 rev. 5, 21 I.L.M. 58, available at http://www.achpr.org/files/instruments/achpr/banjul_charter.pdf (last visited Jan. 24, 2014).

113 Id. art. 4.

114 Id. art. 5.

115 Id. art. 5.

116 Id. art. 6.

117 Id. art. 7; see also art. 25 (outlining the State parties' duty to promote the rights and freedoms contained in the Charter, to educate their constituencies about them, and ensure they are understood).

118 Id. art. 9.

119 Id. art. 14.

120 Submission of State Reports, AFrican COMM'N ON HuM. \& PEOPLES' RTS., http://www.achpr.org/ (last visited Jan. 24, 2014).

121 CONST. Of THE Republic OF S. Afr., Dec. 18, 1996, ch. 2.

122 The CONST. OF INDIA, Nov. 26, 1949, art. 300A.
} 
Germany,123 Spain,124 Colombia,125 and Brazil,126 have explicitly incorporated human rights principles into their constitutions.127 For example, Belgium's constitution requires that its citizens be able to "lead a life in conformity with human dignity." 128 Other nations have given international human rights instruments the force of domestic law. For instance, the U.K. passed the Human Rights Act of 1998, which adopts the European Convention on Human Rights as domestic legislation and provides an enforcement mechanism for it. ${ }^{129}$ In some nations, legislation or case law may provide for domestic law to permit causes of action for human rights treaty obligations. ${ }^{130}$ Again, even nations that do not refer explicitly to human rights in their constitution in fact protect human rights; for example, by prohibiting discrimination or protecting privacy rights or rights to due process. ${ }^{131}$

\section{HUMAN RIGHTS IMPLICATED IN ADDRESSING OVER-INDEBTEDNESS}

The previous Part provided a brief overview of the instruments

\footnotetext{
123 GrundGesetZ FÜR DIE BundesRePublik Deutschland [GRUNDGESETZ] [GG] [BASIC LAW], May 23, 1949, BGBI. I (Ger.).

124 C.E., B.O.E. n. 47, Dec. 29, 1978 (Spain).

125 Constitución Política De Colombia [C.P.] arts. 11-26.

126 CONSTITUIÇÃo FEDERAL [C.F.] [CONSTITUTION] (Braz.).

127 Mark Tushnet, The Inevitable Globalization of Constitutional Law, 50 VA. J. INT'L. L. 985, 986 (2009) (describing the "postwar paradigm" of constitutional law as one that "implements national commitments to the protection of basic human rights through proportionality tests licensed by explicit (or sometimes implicit) limitations clauses."). See, e.g., David Law \& Mila Versteeg, The Declining Influence of the United States Constitution, 87 N.Y.U. L. REV 762, 833-47 (2012) (discussing the influence of human rights instruments on constitutions).

1281994 CONST. art. 23 (Belg.).

129 Human Rights Act 1998, ch. 42, NAT'L ARCHIVES, available at

http://www.legislation.gov.uk/ukpga/1998/42/contents (last visited Jan. 24, 2014).

130 See Penny Venetis, Making Human Rights Treaty Law Actionable in the United States: The Case for Universal Implementing Legislation, 63 ALA. L. REV. 98, 136 (explaining that some U.S. courts have found that 42 U.S.C. § 1983 protects rights secured by the Vienna Convention on Consular Relations (VCCR), although most courts have held that $\S 1983$ does not provide actionable individual rights or propose legislation to implement human rights treaties).

131 See, e.g., Law \& Versteeg, supra note 127, at 774 (providing a table discussing the number of countries that provide for various rights).
} 
that establish human rights obligations and described some of the international bodies responsible for enforcing these obligations. This Part explores in detail those protected human rights that can inform responses to over-indebtedness. For nations that are considering how to address issues of over-indebtedness and that have either undertaken human rights obligations or wish to adhere to human rights standards, this Part can serve as a guide.

Because my expertise is in the area of U.S. insolvency law, I devote much of my analysis to considering how a human rights approach might affect policy choices in the U.S. Although the U.S. has not signed on to the International Covenant of Social, Economic, and Cultural Rights, we have signed on to the International Covenant of Civil and Political Rights. In addition, there are a number of policy makers who agree with the human rights standards enshrined in the ICCPR and who might like to ensure that the U.S.'s response to over-indebtedness is consistent with these principles. What is notable is that the current system for responding to over-indebtedness, while considered by many to be the most liberal response to over-indebtedness, in fact fails to satisfy human rights standards. This does not mean that the insolvency regime is to blame for the weakness in satisfying human rights principles; rather, the weak U.S. social safety net and gaps in consumer protection leave a hefty role for the consumer bankruptcy system. However, as I will discuss, there are some aspects of the bankruptcy system itself that do raise human rights concerns. While I do not here argue that policymakers should necessarily craft a response to over-indebtedness that is consistent with human rights principles, I demonstrate that the current system does accomplish this. In other words, our current frameworks and policy goals have left us with significant gaps from a human rights lens.

Although much of my discussion is U.S.-focused, I do include some examples from other nations to demonstrate that these issues are not unique to the U.S. However, there is not room here for a discussion of each nation's laws addressing consumer overindebtedness. Nevertheless, policymakers and lawmakers can evaluate their responses to consumer over-indebtedness using this analysis.

\subsection{Adequate Standard of Living}

The ICESCR recognizes the right to "an adequate standard of 
living" for the individual and his or her family, including "adequate food, clothing and housing, and to the continuous improvement of living conditions."132 While the Committee on Economic, Social, and Cultural Rights does not have enforcement capacity, it has issued comments concluding that nation states as well as the private business sector have obligations to ensure adequate living standards. ${ }^{133}$ Economic, social, and cultural rights are only minimally addressed in the ACHR and ECHR. ACHR signatories commit to the progressive realization "of the rights implicit in the economic, social, educational, scientific, and cultural standards" set forth in the Charter. ${ }^{134}$ The ECHR, in its additional protocols, provides for the right to education but no other substantive positive right. ${ }^{135}$

Over-indebtedness may interfere with rights to adequate food and housing because individuals may not have enough money left over after paying creditors in order to provide for these needs. As a result, some individuals may be so over-indebted that they cannot meet their basic needs or the basic needs of their dependents. They may be trapped in a cycle of ever-increasing debt obligations as fees and interest mount, leaving less and less disposable income to satisfy fundamental needs. They may be forced to turn over virtually all of the fruits of their labor to creditors indefinitely. Children of over-indebted individuals may also lack access to food or housing. ${ }^{136}$ Elder indebted individuals

132 ICESCR, supra note 81, art. 11, §1.

133 UN Comm. on Econ., Soc. \& Cultural Rts., supra note 84, at General Comment 12: The Right to Adequate Food, art. 11, ๆ 20; General Comment 14: The Right to the Highest Attainable Standard of Health, art. 12, ๆ 42.

134 American Convention, supra note 93, art. 42.

135 Council of Eur., Protocol to the Convention for the Protection of Human Rights and Fundamental Freedoms as amended by Protocol No. 11, art. 2, Mar. 20, 1952 [hereinafter First Protocol], available at http://conventions.coe.int/Treaty/en/Treaties/Html/009.htm (last visited Jan. 25, 2014).

136 World Bank Report, supra note 1, at 26-27.

Over-indebtedness may result in exclusion of individuals and families from society, including a loss of motivation to be engaged in income-generating activities, exclusion from social activities, and health problems. This is not only detrimental to the individuals and families concerned, but also to society as a whole as it suffers evident financial loss. That is why one of the paramount objectives of rehabilitation should be social and financial inclusion of overindebted individuals and families.

Council of Europe Recommendation, supra note 10, at 17. 
may be particularly at risk of being unable to meet their basic needs because their ability to accumulate new income is limited.

Aggressive debt collection can interfere with debtors' rights to adequate food and housing, although "most societies have decided that debtors cannot be left with no assets whatsoever with which to support themselves and their families."137 Nations often limit creditors' remedies by enacting exemption laws that protect debtors' basic needs; for example, basic household goods, protection from excessive wage garnishment, and protection of the debtor's home. However, exemption levels vary widely from one jurisdiction to the next.

In the United States, although the Federal Consumer Credit Protection Act provides that no more than twenty-five percent of consumer wages may be garnished,138 exemption levels vary tremendously from state to state. Some jurisdictions require debtors to live at "close to poverty levels," permitting debtors to retain only tools of the trade, wearing apparel, and bedding, and only up to a limited value. ${ }^{139}$ Other jurisdictions allow creditors to garnish much of debtors' wages, meaning that the debtor is unable to retain sufficient income to maintain a standard of living that is consistent with human dignity. Absent an opportunity for debt relief, debtors could be "confine[d] to a distressed state indefinitely." 140 In many jurisdictions, even where the debtor is entitled to some exemptions, "any future excess property or earnings beyond the exemption limits remain available to creditors, often indefinitely." 141 In forty-one states in the United States, exemption laws do not protect a living wage, and twenty states permit such extensive garnishment that an individual who earns minimum wage is left with wages that fall below the poverty line, and a family of four making minimum wage can be left with less than half of the federal poverty guideline. ${ }^{142}$ In such situations, creditors will reap the benefits of debtors' labor rather than the debtor and his/her family.

137 World Bank Report, supra note 1, at 76.

13815 U.S.C. § 1671 et seq.; 29 CFR § 870.

139 World Bank Report, supra note 1, at 78.

$140 \quad$ Id. at 71.

141 Id. at 76

142 Carolyn Carter \& Robert Hobbs, No Fresh Start: How States Let Debt Collectors Push Families into Poverty, NAT'L CONSUMER L. CTR. (Oct. 2013), available at http://www.nclc.org/images/pdf/pr-reports/report-no-fresh-start.pdf. 
There is also tremendous variation among states with respect to which assets debtors can retain. Some states do not leave debtors with even basic household goods. Pennsylvania, for example, protects only clothing, Bibles, schoolbooks, sewing machines, military uniforms, and $\$ 300$ worth of other property an amount grossly insufficient for preserving furniture and appliances. ${ }^{143}$ Likewise, Vermont exempts only one cow, two goats, three swarms of bees, and one vehicle worth $\$ 2500$ or less. ${ }^{144}$

Other jurisdictions permit full exemptions for certain categories of assets, including the debtor's home, household goods, tools of the trade, health aids, and in some cases unmatured life insurance or retirement. ${ }^{145}$ Those unable to work may need additional protection - exempting debtor's pensions and retirement assets from collection would help protect an adequate standard of living for the elderly. In some countries, unvested pension trusts are protected whereas contractual agreements or retirement savings are not. ${ }^{146}$

If exemption laws and social safety nets are insufficient to protect debtors' rights to an adequate standard of living, a debt relief regime may be one method of restoring individuals' basic needs. In the United States, federal bankruptcy exemptions mitigate the effect of some states' meager exemption laws, but only in those states that permit debtors to "opt-out" of the state exemption laws in bankruptcy. ${ }^{147}$

Where reducing the cost of servicing debt allows debtors to meet their basic needs, an insolvency regime may be an effective way of satisfying the human rights compliant standard of living. In many cases, of course, an individual's inability to meet basic needs is a combination of insufficient income and overindebtedness. Income shortfall may lead to a need to access credit which exacerbates the income shortfall as the individual must devote increasing income to servicing the debt, often including mounting interest and fees. In some cases, income is sufficient so that debt relief alone will enable the debtor to meet his or her basic needs, while in many other cases the problem is the broader problem of poverty. Although insolvency systems may contribute

14342 Pa. Cons. StAT. ANN. § 8124 (West 2013).

144 VT. StAT. AnN. tit. 12, § 2740 (2013).

145 World Bank Report, supra note 1, at 77-78.

146 Id. at 82-83.

$147 \quad 11$ U.S.C. $\S 522$. 
to ameliorating adequate living concerns, there are limits to what insolvency regimes can accomplish. Relieving individuals from debt will only help if the cause of the inadequate living standard is indebtedness. There are many impoverished individuals who are not indebted, so debt relief will not be an exclusive solution to the challenge of meeting the basic needs of individuals. However, in countries where over-indebtedness creates or exacerbates situations of poverty, a debt relief regime can be a helpful tool.

If a nation chooses an insolvency regime as a method of protecting the basic needs of debtors, the insolvency regime itself will also need to permit the debtor to retain sufficient assets to satisfy this human rights concern. The exemption levels required in order to protect the debtor's human rights to basic subsistence depends upon whether the jurisdiction provides for some minimal level of support adequate to satisfy such requirements. Debtors should retain "sufficient property to meet post-insolvency minimum domestic needs for themselves and their families and, where necessary, minimum business needs." 148 If exemption laws sufficiently protect debtors' wages, housing, and other essentials, and/or if the state guarantees adequate housing and basic needs apart from exemption laws, debt relief may not be necessary to satisfy this particular right; however, it is certainly likely to be one component of addressing such concerns, particularly for those nations that are averse to robust, taxpayer-funded social safety nets. Alternatively, or additionally, nations may provide a robust safety net for individuals with income shortfalls and may not need to rely as heavily on an insolvency regime. Nations that provide generous support to elders may not be as concerned about debt relief for elders. If food and housing consistent with human dignity is available, debt relief may be somewhat less important. However, even if nations provide a robust welfare system that ensures an adequate standard of living for its residents, the state of perpetual indebtedness and an inability to be self-sufficient may infringe on human dignity, as discussed subsequently. Because the United States has elected to provide a relatively weak social safety net, it may need to rely disproportionately on debt relief to ameliorate the income shortfalls and attendant food and housing concerns. Providing an opportunity to discharge debt relatively quickly can partially offset, in some cases, the government's

\footnotetext{
148 World Bank Report, supra note 1, at 76.
} 
decision to devote relatively fewer resources to housing. In addition, careful exemption laws, such as restricting garnishment of low-income individuals, is more critical in cases where the government is unable or unwilling to provide sufficient support to meet basic needs.

\subsection{Right to Healthcare}

The ICESCR also provides for the right to the "highest attainable standard of physical and mental health."149 Overindebtedness impacts access to healthcare in two ways: it decreases the funds available to pay for health care and also can be the cause of health problems. Indeed, health expenses are one of the key causes of over-indebtedness in some countries, particularly in the United States. ${ }^{150}$

The health problems that have been linked to overindebtedness include both psychological and physical trauma. Studies have consistently found evidence that debt burdens can lead to anxiety, depression, and social withdrawal. Suffering from debt loads can even lead to physical illness, including sleep deprivation, lack of concentration, indigestion, heart problems, nerve problems, and even suicide. ${ }^{151}$ Debt relief regimes may ameliorate the psychological trauma caused by over-indebtedness - relief from debt obligations has been shown to relieve anxiety

149 ICESCR, supra note 81, art. 12.

150 David Himmelstein, Deborah Thorne, Elizabeth Warren \& Steffie Woolhandler, Medical Bankruptcy in the United States, 2007: Results of a National Study, 122 AM. J. MED. 743, 743-44 (2009).

151 World Bank Report, supra note 1, at 25-27 (citing Laura Choi, Federal Reserve Bank of San Francisco, Financial Stress and Its Physical Effects on Individuals and Communities, 5 CMTY. Dev. INV. Rev. 120 (2009); AP-AOL/ABT SRBI, Credit Card / Debt Stress Study (2008), available at http:/ / surveys.ap.org/data/SRBI/APAOL \%20Health\%20Poll\%20Topline\%20040808_FINAL_debt\%20stress.pdf; Nigel Balmer, Pascoe Pleasence, et al., Worried Sick: The Experience of Debt Problems and Their Relationship with Health, Illness and Disability, 5 SOC. POL'Y \& SOC'Y 39 (2006)); Burcu Duygan-Bump \& Charles Grant, Household Debt Repayment Behaviour: What Role Do Institutions Play?, 24 ECON. PoL'y 107 (2009); Sarah Emami, World Health Org., Consumer Over-Indebtedness and Health Care Costs: How to Approach the Question from a Global Perspective, Background Paper 3, World Health Report (2010); Fr. Bang Olsen, Social-retspleje, ADVOKATBLADET, nr. 1 (1972); see also Melissa B. Jacoby, Does Indebtedness Influence Health? A Preliminary Inquiry, 30 J.L. MED. \& ETHICS, 560-71 (2002). 
and other stress reactions to over-indebtedness. 152 In one study of over 1,300 debtors in New York, Chicago, Detroit, and Philadelphia, nearly half of debtors reported health problems. ${ }^{153}$ Another study of 970 individuals in Ohio found that a high debt to income ratio was significantly associated with poor physical health. ${ }^{154}$ Other studies have found over-indebtedness to be associated with higher incidences of periodontal disease ${ }^{155}$ and even melanoma. ${ }^{156}$ Even worse, debtors who faced significant creditor collection harassment were far more likely to report health problems than debtors who were not targeted aggressively. ${ }^{157}$

Of course, the ability of debt relief to ameliorate stress-induced health problems will work only if debt is the primary source of stress - if job loss, family break-up, or general financial instability is also a primary cause of the stress, these matters will also have to be addressed.

Not only can debt lead to health problems, but over-indebted individuals also may lack sufficient resources to pay for health insurance and/or health treatment, including preventative care and emergency care. Some individuals may be unable to satisfy their basic living needs or pay for future healthcare specifically as a result of excessive medical debt. If individuals lack access to affordable health insurance or affordable medical care, it is possible that some of them may not seek treatment absent an ability to ultimately escape debt burdens incurred; or these individuals may have to choose among meeting their need for food, housing, or proper medical care. Nations that provide their citizens with free high quality healthcare will not face this problem. Although over-indebtedness may raise other concerns, overindebtedness will not prevent access to healthcare. In contrast, in

152 See, e.g., Götz Lechner \& Wolfram Backert, Menschen in der Verbraucherinsolvenz: Rechtliche und soziale Wirksamkeit des Verbraucherinsolvenzverfahrens einschließlich Darstellung der Haushaltsstrukturdaten des untersuchten Personen-kreises, in BMFSFJ, MATERIALIEN ZUR FAMILIENPOLITIK: LEBENSLAGEN VON FAMILIEN UND KINDERN: ÜBERSCHULDUNG PRIVATER HAUSHALTE 33-54 (2008).

153 David Caplovitz, Consumers in Trouble: A Study of Debtors in DeFAULT 8 (1974).

154 Patricia Drentea \& Paul J. Lavrakas, Over the Limit: The Association Among Health, Race and Debt, 50 Soc. SCI. \& MED. 517, 518 (2000).

155 R.J. Genco et. al., Relationship of Stress, Distress and Inadequate Coping Behaviours to Periodontal Disease, 70 J. PeRIODONTOLOGY 711, 711-23 (1999).

156 R.J. Havlik, A.P. Vukasin \& S. Ariyan, The Impact of Stress on the Clinical Presentation of Melanoma, 90 PLASTIC \& RECONSTR. SURGERY 57, 57-61 (1992).

157 CAPLOVITZ, supra note 153 , at 288. 
countries without affordable healthcare, such as the United States, debt relief may be a crucial part of meeting the right to healthcare. If health costs can be incurred on credit and discharged in bankruptcy, individuals may be able to have sufficient access to healthcare even when income is insufficient. In such a situation the cost of debt relief would be initially born by the medical creditor (the healthcare provider), but costs could be ultimately passed on to non-defaulting recipients of medical care. The system thus functions as a form of insurance, albeit an inefficient one.

The intersection between nations' health care systems and insolvency regimes is particularly important in light of the causal link between medical debt and over-indebtedness. ${ }^{158}$ In the United States, for example, over half of consumer bankruptcies can be attributed in part to medical costs. ${ }^{159}$ Indeed, empirical evidence suggests that increased health coverage is linked to a decrease in problems associated with over-indebtedness; a study by the Chicago Federal Reserve demonstrated Massachusetts' universal health care legislation was associated with a decrease in debt, third party debt collection actions, and bankruptcies. ${ }^{160}$

Thus, lack of a robust health care system can be the cause of over-indebtedness, which in turn can cause health problems, and which also can lead to a decreased ability to pay for health care. A policy decision to let an insolvency regime do much of the work for protecting rights to healthcare is not only inefficient but is also unlikely to be a complete solution from a human rights perspective. Debt relief can provide some relief for individuals suffering health problems due to over-indebtedness or suffering health problems that will cause over-indebtedness, but medical treatment will still be necessary.

\subsection{Right to Work and "Favorable" Remuneration}

Article 23 of the Universal Declaration of Human Rights

158 Himmelstein et al., supra note 150, at 743-44 (providing empirical evidence of the link between medical expenses and the need for debt relief).

159 Id.

160 Bhashkar Mazumder \& Sarah Miller, The Effects of the Massachusetts Health Reform on Financial Distress, FED. RES. BANK CHI. (2014), available at http://chicagofed.org/webpages/publications/working_papers/2014/wp_01.cf $\mathrm{m}$. 
provides that "everyone has the right to work" and that workers have "the right to just and favorable remuneration ensuring for himself and his family an existence worthy of human dignity, and supplemented, if necessary, by other means of social protection." 161 The International Labor Organization is also responsible for monitoring and protecting rights to work. ${ }^{162}$ The Right to Work is one of the human rights explicitly mentioned in international insolvency work; the World Bank Report expressly concludes that nations' choice of treatment of over-indebtedness implicates the rights to work and fair pay. ${ }^{163}$ The Report does not elaborate as to how specifically the right to work might be implicated, but there are at least two ways that indebted individuals' rights to work and receive fair remuneration could be imperiled due to overindebtedness. First, debt collection laws may permit excessive wage garnishment, leaving the individual with insufficient remuneration to meet basic needs. In addition, because the primary benefit of labor will inure to creditors rather than to the worker, excessive garnishment may deter employment.

Second, not only can collection laws leave the debtor with insufficient remuneration, but collection laws may also permit employers to terminate individuals whose wages are garnished, thus interfering with the right to work. 164 In the United States, for example, although employers may not discriminate against employees who have a single garnishment order against them, employers may discriminate against (whether by terminating or failing to hire) individuals with more than one garnishment order against them. ${ }^{165}$ In addition, in some places employers are permitted to fire or fail to hire individuals based on their credit scores.166 In other words, individuals who are excessively

\footnotetext{
161 Universal Declaration of Human Rights, supra note 66, art. 23, §§ 1, 3.

162 See Applying and Promoting International Labour Standards, INT'L LABOR ORG., $\quad$ http://www.ilo.org/global/standards/applying-and-promotinginternational-labour-standards/lang-en/index.htm (providing a description of the supervisory structure and functions of the ILO in supervising the application of labor standards).

163 World Bank Report, supra note 1, at 50.

164 Termination on such grounds also violates anti-discrimination principles. See 15 U.S.C. § 1674 (2012).

165 See id. (employers may not terminate employees for "any one" garnishment order - there is no prohibition on termination if an employee is subject to multiple garnishment orders).

166 Gary Rivlin, The Long Shadow of Bad Credit in a Job Search, N.Y. TIMES (May 11, 2013), http://www.nytimes.com/2013/05/12/business/employers-pull-
} 
financially distressed are most at risk of termination.

If collection laws interfere with the debtors' right to work or receive just pay, an accessible debt relief regime providing an opportunity for relief from such collection methods may protect these rights. For example, a bankruptcy filing could trigger an automatic stay ceasing collection activities including garnishment. ${ }^{167}$ Bankruptcy or insolvency proceedings could also provide an opportunity for the discharge or reorganization of debt so that the debtor can retain sufficient income. Halting garnishment and providing an opportunity to discharge or reorganize the debt upon which the garnishment orders are based would also prevent barriers to employment. Of course, the insolvency regime would also have to protect against interference with the right to work; for example, employers should not be permitted to fire or fail to hire individuals solely because of a bankruptcy filing. ${ }^{168}$

An insolvency regime is not the only way to address these concerns, however; restrictions on garnishment or restrictions on firing due to garnishment or other debt-related issues would also prevent interference with the rights to work and receive just remuneration for labor. Whether an insolvency regime is required to protect the rights to work and receive just remuneration depends on the jurisdiction's background rules including limitations on debt collection and restrictions on termination of over-indebted individuals.

\subsection{Prohibition on Incarceration for Failure to Pay Debt}

In some jurisdictions, failure to pay debt can result in the debtor being deprived of liberty, a condition that violates human rights standards and obligations. In some states in the United States, for example, debtors may be imprisoned for contempt of

applicants-credit-reports.html. A new bill proposed by Senator Elizabeth Warren would prohibit employers from conducting credit checks on prospective employees. Noah Bierman, Proposal Would Ban Employers from Looking at Credit History, BOston GLOBE (Dec. 17, 2013), http://www.bostonglobe.com/news/politics/2013/12/17/elizabeth-warrenmeasure-would-forbid-employers-from-looking-job-applicant-credithistory/mRgMmewBKxTI9i71wsMJXP/story.html.

167 See, e.g., 11 U.S.C. § 362 (2012) (discussing automatic stays in bankruptcy).

16811 U.S.C. $\S 525$. 
court orders to pay creditors. A number of human rights instruments prohibit imprisonment for failure to pay a debt. Both the ICCPR and the ECHR provide that "[n]o one shall be imprisoned merely on the ground of inability to fulfill a contractual obligation."169 The ACHR provides that "[n]o one shall be detained for debt, 170 but permits detention if ordered by a "competent judicial authority for the nonfulfillment of duties of support." 171

Although "debtor's prisons" as such have been abolished, in the United States, a full third of states indirectly permit incarceration for failure to pay debt, including medical debt, credit card debt, and automobile loans. ${ }^{172}$ Failure to pay debt does not automatically lead to incarceration, but debtors can be arrested for contempt of court orders that require them to appear or pay legal fines in connection with collection proceedings. ${ }^{173}$ In advocating for legislation prohibiting incarceration in connection with creditor actions, Illinois Attorney General Lisa Madigan objected that many residents "have been thrown in jail simply because they're too poor to pay their debts." 174 Liberty deprivation triggered by a default on debt is inconsistent with human rights principles. Although international human rights law may not prohibit incarceration of individuals who are able but unwilling to pay debts, many of those incarcerated for contempt of court orders to pay have demonstrated an inability to pay. ${ }^{175}$

In addition to incarceration related to creditor actions, individuals can be incarcerated for failure to pay legal debts in a number of states.176 For example, one woman was incarcerated four times because she did not pay $\$ 251$ in court costs and fines

169 ICCPR, supra note 62, art. 11. The European Convention on Human Rights did not initially include a prohibition on detention or imprisonment on account of default, but Article 1 of the 1963 Protocol prohibits deprivation of liberty "merely on the ground of inability to fulfill a contractual obligation." Council of Europe, The European Convention on Human Rights, art. 1 [hereinafter The European Convention on Human Rights], available at http://www.hri.org/docs/ECHR50.html (last visited Jan. 25, 2014).

170 American Convention, supra note 93, art. 7, § 7.

171 Id.

172 Alain Sherter, Jailed for \$280: The Return of Debtors' Prisons, AxIS OF LOGIC (Apr. 28, 2012), http:/ /axisoflogic.com/artman/publish/Article_64490.shtml.

173 Id.

$174 \quad I d$.

175 Id.

176 Id. 
related to her fourth-degree misdemeanor case. ${ }^{177}$ The American Civil Liberties Union stated:

The sad truth is that debtors' prisons are flourishing today, more than two decades after the Supreme Court prohibited imprisoning those who are too poor to pay their legal debts. In this era of shrinking budgets, state and local governments have turned aggressively to using the threat and reality of imprisonment to squeeze revenue out of the poorest defendants who appear in their courts. ${ }^{178}$

In some cases court systems add a collection fee to the original fine or refer collection of legal fees to collection agencies entitled to add collection fees. ${ }^{179}$ The collection fees can be as high as thirty or forty percent of the original debt. ${ }^{180}$ Very minor infractions - such as speeding - can lead to fines and incarceration. For example, one Alabama woman initially received a $\$ 179$ speeding ticket, but after missing the court date fees mounted to over $\$ 1500$. She was then jailed and her case turned over to a probation company, which resulted in even greater fees (ultimately totaling over $\$ 3,000$ ) and further instances of incarceration as a result of her failure to pay. ${ }^{181}$ Although imprisonment for failure to pay legal fees may not be, in the first instance, punishment due to inability to pay a debt, imprisonment due to inability to pay a legal fine violates the prohibition whether the imprisonment is considered "punishment" or not.

Incarceration has a number of other deleterious consequences

177 Id.

178 Id.

179 Id. Ethan Bronner, Poor Land in Jail as Companies Add Huge Fees for Probation, N.Y. TIMES (July 2, 2012),

http:/ / www.nytimes.com/2012/07/03/us/probation-fees-multiply-ascompanies-profit.html?smid=pl-share.

180 Sherter, supra note 172.

Some states also apply 'poverty penalties,' including late fees, payment plan fees, and interest when people are unable to pay all their debts at once, according to a report by the New York University's Brennan Center for Justice. Alabama charges a 30 percent collection fee, for instance, while Florida allows private debt collectors to add a 40 percent surcharge on the original debt. Id.

181 Bronner, supra note 3. 
that imperil debtors' human rights - it interferes with the debtors' ability to maintain employment and housing, in addition to preventing the debtor from meeting the basic subsistence needs of himself and his dependents. ${ }^{182}$

Of course, the simplest and surest solution to this human rights infraction would be to ban any incarceration resulting from failure to pay a debt. Indeed, a debt relief regime is likely insufficient to remedy this human rights violation-any such incarceration for failure to pay debt is inconsistent with human rights principles. As an interim matter, debt relief regimes can provide an escape from state law in situations in which incarceration raises human rights concerns. For debtors unable to pay support debts, debt relief regimes may be one solution for ensuring payment of support debts; in some cases it may only be possible for debtors to pay support obligations if other consumer debt obligations are relieved.

\subsection{Prohibition on Debt Peonage}

Under certain circumstances, debt servicing may give rise to a condition similar to peonage, which would interfere with the debtors' right to be free from servitude. The ICCPR, ECHR, and ACHR all prohibit slavery, servitude, and "forced or compulsory labor." 183 The ACHPR does not prohibit forced labor. Debt

182 Sherter, supra note 172.

Many states are imposing new and often onerous 'user fees' on individuals with criminal convictions,' the authors of the Brennan Center report wrote. 'Yet far from being easy money, these fees impose severe-and often hidden-costs on communities, taxpayers, and indigent people convicted of crimes. They create new paths to prison for those unable to pay their debts and make it harder to find employment and housing as well to meet child-support obligations.

Id.

183 Article $8, \S 2$ and $\S 3$ of the ICCPR prohibits slavery and servitude "in all their forms," as well as "forced or compulsory labor." ICCPR, supra note 62, art. 8, $\S \S 2,3$. Article 4 of Section 1 of the European Convention on Human Rights prohibits slavery, servitude, and "forced or compulsory labor." Id. art. 4, § 1 . Work compelled in the course of detention, emergency, military, or "civic obligations" is not considered forced or compulsory. Convention for the Protection of Human Rights and Fundamental Freedoms, supra note 101, art. 4, § 1. The American Convention on Human Rights prohibits slavery and involuntary servitude "in all their forms" and also prohibits "forced or compulsory labor." American Convention, supra note 93, art. 6, §§ 1,2. Labor in the course of criminal punishment, military service, "danger and calamity," or civic obligation is not 
bondage is also prohibited in the Supplementary Convention on the Abolition of Slavery, the Slave Trade, and Institutions and Practices Similar to Slavery. ${ }^{184}$ Debt bondage is defined as:

the status or condition arising from a pledge by a debtor of his personal services or of those of a person under his control as security for a debt, if the value of those services as reasonably assessed is not applied towards the liquidation of the debt or the length and nature of those services are not respectively limited and defined. ${ }^{185}$

Peonage refers to the practice of requiring an individual to work to pay off a creditor as a condition of default, often providing for imprisonment in the alternative. ${ }^{186}$ Peonage is not equivalent to slavery or even involuntary servitude; peons, in contrast to slaves and indentured servants, had freedom of movement and full rights of citizenship, including the right to vote.187 In cases where the issue of forced or compulsory labor has actually been adjudicated, the definition of forced labor is quite narrow. Under the European Convention, for example, the Commission held that not only must the labor be "exacted . . . under menace of any penalty," but must also be work for which the person "has not offered himself voluntarily," that is, pursuant to a labor contract. ${ }^{188}$ Under the

forced or compulsory. Id. art. $6, \S 3$.

184 United Nations, Supplementary Convention on the Abolition of Slavery, the Slave Trade, and Institutions and Practices Similar to Slavery, Apr. 30, 1957, 266 U.N.T.S. 3, available at http:/ / www1.umn.edu/humanrts/instree/f3scas.htm.

185 Id.

186 Jaremillo v. Romero, 1 N.M. 190, 190-208 (S. Ct. 1857); Karen Gross, The Debtor as Modern Day Peon: A Problem of Unconstitutional Conditions, 65 Notre DAME L. REV. 165, 178-79 (1990). For background information on laws against peonage, see generally T. EMERSON, D. HABER \& N. DORSEN, EMERSON, HABER \& DORSEN's POLITICAL AND CiVIL RIgHTS IN THE UNITED STATES 517-20 (4th ed. 1976); B. SCHWARTZ, A COMMENTARY ON THE CONSTITUTION OF THE UNITED STATES: RIGHTS OF THE PERSON 2 (1968); STATUtORY History OF tHE United StATES: Civil Rights, PART I (B. Schwartz ed., 1970); Cyril C. Means, Jr., Surrogacy v. The Thirteenth Amendment, 4 N.Y.L. SCH. J. HuM. RTS. 445 (1987); Robert L. Misner \& John H. Clough, Arrestees as Informants: A Thirteenth Amendment Analysis, 29 STAN. L. Rev. 713 (1977); Benno C. Schmidt, Jr., Principle and Prejudice: The Supreme Court and Race in the Progressive Era - Part 2: The Peonage Cases, 82 ColuM. L. REV. 646 (1982).

187 Gross, supra note 186, at 177-78.

188 Siliadin v. France, 2005-VII Eur. Ct. H.R., available at http://hudoc.echr.coe.int/sites/eng/pages/search.aspx\#\{"appno":["73316/01"],"i 
European Convention, labor must be both: 1) against the individual's will, and 2) either the work obligation must be "unjust" or "oppressive," or must be "an avoidable hardship" (having some element of harassment). ${ }^{189}$ However, anti-peonage laws were passed pursuant to Section Two of the Thirteenth Amendment, and violation of anti-peonage laws has thus been considered a Thirteenth Amendment violation. ${ }^{190}$ Individuals can work for creditors voluntarily; labor takes the form of peonage only if it is coerced with threats of harm or imprisonment. 191

Some scholars have drawn parallels between extended overindebtedness and peonage, writing that both conditions "separate individuals from the benefits of their own labor."192 Individuals required to devote all future earnings to creditors "would be separated from their own labor and subordinated to creditors," and the legislation permitting such condition "would become a means of enslaving debtors to their creditors." 193 In fact, U.S. lawmakers originally defended bankruptcy discharge specifically on the basis that absence of such relief would be akin to a condition of bondage. ${ }^{194}$

temid":["001-69891 (citing Van der Mussele v. Belgium, 70 Eur. Ct. H.R. (ser. A) (1983)).

189 Iversen v. Norway, Application No. 1468/62, 6 Y.B. Eur. Conv. On H.R. 327, 327-29 (1963). As mentioned above, the International Labour Organization has its own jurisprudence on the issue of forced labor.

190 Gross, supra note 186, at 177; U.S. CONST. amend. XIII, § 2 ("Congress shall have power to enforce this article by appropriate legislation."); see also Clyatt v. United States, 197 U.S. 207, 218 (1905) (holding that Congress has power to pass Anti-Peonage laws).

191 Gross, supra note 186, at 180 n.96 (citing United States v. Kozminski, 821 F.2d 1186 (6th Cir. 1987), aff'd in part, 108 S. Ct. 2751 (1988)).

192 Id.

193 Id. at 165.

194 Id. at 166 n.8 (citing CONG. GLOBE, 27th Cong., 1st Sess. 318 (1841) (statement of Rep. Roosevelt) ('Talk of slavery and abolition! What slavery was to compare with the bondage of the mind and heart?"); Bankruptcy Reform: Hearing Before the Subcomm. on Courts of the Senate Comm. on the Judiciary, 98th Cong., 1st Sess. 257 (1983) (statement of Lawrence P. King, Prof. of L., N.Y.U. L. Sch.) [hereinafter King Statement] (stating that the proposal, "while perhaps not technically violative of the 13th Amendment to the Constitution comes very close to it in word and in spirit."); Bankruptcy Reform Act of 1978 (Future Earnings): Hearing Before the Subcomm. on Courts of the Senate Comm. on the Judiciary, 97th Cong., 1st Sess. 142 (1981) (statement of Vern Countryman, Prof. of L., Harvard Univ. L. Sch.) [hereinafter Countryman Statement] ("We would [be] turn[ing] our backs on our history ... if we were now to enact a mass peonage statute whereby the debtor's discharge is to be delayed for a 5-year period of bondage ...."). 
In order to satisfy human rights standards, debtors cannot be forced work to repay creditors. Rather, debtors must be permitted to opt in to such plans or they would likely constitute peonage. ${ }^{195}$ Some countries require debtors seeking relief to enter into lengthy repayment plans. For example, in the United States, Chapter 13 requires certain debtors to repay creditors from their future income for a period of three to five years. Denmark has five-year repayment plans, ${ }^{196}$ and France and Germany have six-year repayment plans. ${ }^{197}$ Debtors in such repayment plans are required to work and to devote the fruits of this labor to creditors for an extended period.

Although the lack of access to a prompt discharge alone would not be akin to peonage, there are circumstances under which a debtor may be deemed "forced" into repayment plans. For example, if the debtor must choose between labor and harm or imprisonment, the "choice" of repayment may be a forced one, and the relationship thus impermissible.

In the U.S., for example, there may be circumstances in which the debtor is in essence forced to choose between work and imprisonment; for example if imprisonment is a consequence for unpaid bad checks, failure to pay a tort judgment, or failure to pay a domestic support obligation. 198 If discharge is unavailable and

19511 U.S.C. §§ 109, 301 (2012); ROBERT L. JORDAN \& WILLIAM D. WARREN, BANKRUPTCY 662-63 (2d ed. 1989); B. WeINTRAub \& A. RESNICK, BANKRUPTCY LAW MANUAL (1986); see Gross, supra note 186, at 167-68 (noting that permitting a discharge in bankruptcy only upon working for said benefit may be a constitutional violation).

196 London Economics Report, supra note 5, at 29.

197 Id. at $44,45$.

198 Gross, supra note 186, at 176 (describing a hypothetical in which proceeding in a chapter 13 repayment case is the only way for a debtor who has written a bad check to escape imprisonment and other obligations). Of course, legal realists have long noted that the "choice" not to work is illusory, even for non-indebted individuals. See, e.g., Robert Hale, Coercion and Distribution in a Supposedly Non-Coercive State, 38 POL. SCI. Q. 470, 470-78 (1923); see also Gross, supra note 189, at 181 ("[I]f freedom of chapter choice is eliminated and a debtor refusing to work under a Chapter 13 plan forfeits a bankruptcy discharge and faces imprisonment under state law, then an unconstitutional condition has been placed on discharge.").

While the Bankruptcy Code as written may not create a threat of imprisonment, the Code as applied - in light of state law-creates such a threat. From the perspective of outcome for the individual debtor, there is no meaningful distinction between peonage and bankruptcy. Acontextually, then, Chapter 13 may not be offensive; it does not per se require a debtor to work. It is in the context of other aspects of the 
repayment from future income is the only method for repayment, the combined effect of these laws is likely an impermissible infringement on the right to be free from coerced labor. Since 2005, the U.S. Bankruptcy Code has required the dismissal of a chapter 7 petition for debtors whose income is above the state median and for whom deduction of permitted expenses leaves sufficient disposable income to repay a given portion of creditor claims. ${ }^{199}$ This makes the "voluntariness" of a chapter 13 filing questionable in some cases. ${ }^{200}$ Individuals ineligible for discharge but who are required to repay debt in order to avoid prison are thus coerced into laboring for the benefit of creditors.

Nations do not have to provide for a discharge of debt in order to satisfy their human rights obligation to keep individuals free from coerced labor. However, if non-bankruptcy law provides that the individual must choose between labor and imprisonment, a human rights violation has occurred and can only be remedied by: a) the removal of imprisonment as a consequence of nonpayment or b) discharge of the debt through some kind of insolvency proceeding. ${ }^{201}$ In other words, debt relief regimes can provide an

Bankruptcy Code and more particularly state law that Chapter 13 must be examined.

Id. at 184 (footnote omitted).

199 See 11 U.S.C. § 707(b) (2012) (discussing court power to dismiss a case brought under Chapter 13 while providing criteria for evaluating and accounting for various forms of monthly expenses and disposable income measures).

200 JORDAN \& WARREN, supra note 196, at 662. "If a debtor whose Chapter 7 petition has been dismissed needs protection from creditors, only Chapters 11 and 13 are available. In this sense we have, if not an involuntary Chapter 13 for the consumer debtor, at least a somewhat coerced one." Id.

201 Imprisonment is permissible as punishment for a crime, but bad check actions are actually collection actions in nature rather than punitive. See Gross, supra note 186, at 176 (citing David A. Rice, When Bankruptcy Courts Will Enjoin State "Bad Check" Proceedings: The Decline of the Primary Motivation Standard in Favor of the Younger Abstention Doctrine, 93 CoM. L.J. 111 (1988)); P. Steven Kratsch \& William E. Young, Criminal Prosecutions and Manipulative Restitution: The Use of State Criminal Courts for Contravention of Debtor Relief, in 1984 ANNUAL SURVEY OF BANKRUPTCY LAW 107, 107-09 (1984); James McCafferty \& Gary M. Bubis, Criminal Restitution and the Bankruptcy Discharge: Should We Reopen Debtors' Prison?, 10 CRIM. JUST. J. 27 (1987); see also Gross, supra note 186, at 195:

The argument can be restated forcefully in the following way. One of the roles the anti-peonage laws play is to strike down statutes that provide for imprisonment for failing to work. If, as shown, section 707(b), in concert with state criminal law, is used to coerce debtors into Chapter 13, then an unconstitutional condition is created. The offending statutory provision, in this instance section 707(b), should be struck down. 
escape from situations akin from peonage, but they may also end up facilitating peonage-like situations in which extended periods of labor are required prior to discharge and failure to participate places the debtor at risk of incarceration. ${ }^{202}$

\subsection{Discrimination}

In redressing over-indebtedness, anti-discrimination principles should also be taken into account. Human rights principles prohibit discrimination on the basis of any status, which can include the status of indebtedness or the status of bankruptcy filing. Article 26 of the ICCPR provides that all persons are entitled without any discrimination to the equal protection of the law "and prohibits discrimination on "any ground such as race, colour, sex, language, religion, political or other opinion, national or social origin, property, birth or other status." 203 Article 1 of the ACHR obliges convention parties to "undertake to respect the rights and freedoms" specified and to "ensure to all persons subject to their jurisdiction the free and full exercise of those rights and freedoms, without any discrimination for reasons of race, color, sex, language, religion, political or other opinion, national or social origin, economic status, birth, or any other social condition." 204 Article 14 of the ECHR provides that the protected rights and freedoms "shall be secured without discrimination on any ground such as sex, race, colour, language, religion, political or other opinion, national or social origin, association with a national

202 Paul Krugman has argued that the 2005 bankruptcy amendments, while not creating a condition of peonage, moves closer to creating a condition of peonage by eliminating access to prompt discharge for some individuals. Paul Krugman, The Debt-Peonage Society, N.Y. Times, Mar. 8, 2005, http://www.nytimes.com/2005/03/08/opinion/08krugman.html.

I think the right term is a "debt peonage" society - after the system, prevalent in the post-Civil War South, in which debtors were forced to work for their creditors. The bankruptcy bill won't get us back to those bad old days all by itself, but it's a significant step in that direction.

Id.

203 ICCPR, supra note 62, art. 26.

204 American Convention, supra note 93, art. 1. §§ 1, 2 (explaining that only human beings can be "persons"). 
minority, property, birth, or other status." 205

No distinction in treatment between two groups is permissible without a rational basis and without reasonable proportionality between the means employed and object sought.206 Thus, although neither debtors nor creditors are protected classes, states may not arbitrarily treat similarly situated debtors or creditors differently.

There are several circumstances in which the situation of overindebtedness and responses to over-indebtedness can implicate discrimination principles. If substantive or procedural mechanisms are not equivalent for debtors and creditors, this may raise a discrimination concern under human rights principles. For example, Ecuador, in an action on behalf of its citizens residing in Spain, has alleged that Spain's foreclosure laws discriminate against debtors by arbitrarily limiting the defenses against foreclosure available to debtors. ${ }^{207}$

There are several instances in the United States involving potentially discriminatory situations. For example, the U.S. permits employment discrimination against individuals who are subject to multiple garnishment orders. Furthermore, U.S. employers are increasingly conducting credit evaluations of prospective employees and may decline to hire someone by virtue of their low credit score, bankruptcy filing, or foreclosure record.208 Finally, creditors may be discriminated against if different classes of creditors are treated differently without a rational basis for the differential treatment. For instance, lenders of residential properties have greater rights in the U.S. than lenders of investment properties because the former cannot be modified in bankruptcy while the latter can be reduced to the value of the

205 Convention for the Protection of Human Rights and Fundamental Freedoms, supra note 101, art. 14.

206 Thlimmenos v. Greece [GC], 2000-IV Eur. Ct. H.R. (Apr. 6, 2000), available at http://hudoc.echr.coe.int/sites/eng/pages/search.aspx?i=001-58561 (last visited Jan. 25, 2014). Scholars may view this as more appropriately a due process equal protection concern rather than a discrimination concern, but EU human rights jurisprudence has primarily dealt with arbitrary differences in treatment as a discrimination concern under Article 26 rather than a due process concern, and Article 26 defines equal protection to include anti-discrimination.

207 Petition Before the European Court of Human Rights, Solorzano Verdugo v. Spain 29 (January 18, 2012) (copy of petition on file with author).

208 Gary Rivlin, supra note 167. A new bill proposed by Senator Elizabeth Warren would prohibit employers from conducting credit checks on prospective employees. Bierman, supra note 167. 
collateral.209 In order for a charge of discrimination to hold up, however, the distinction must be shown to be an arbitrary one; employers may argue that over-indebted or bankrupt individuals are indeed less likely to perform well at work. Whether this distinction is arbitrary requires further investigation.

Insolvency legislation may be one method of addressing discrimination concerns if the status of insolvency filing carries with it additional protections from discrimination, such as the prohibition of employment discrimination or guarantees of equitable treatment in the determination of rights or obligations pertaining to credit contracts. However, a direct prohibition on such discrimination may be the most efficient way of accomplishing this goal. An insolvency system may be advantageous if there are insufficient enforcement mechanisms for anti-discrimination issues outside the insolvency system. That is, although there may be legislative prohibitions on discriminatory action, if there is no effective method of redress, the prohibition may not be useful. If insolvency filing gives debtors a protected status and a forum for redressing discrimination, this may aid nations in respecting anti-discrimination principles.

It is also important that the response to over-indebtedness itself not be discriminatory. To put it another way, every debtor should have equal access to the relief available. If the regime offers both repayment plans and prompt discharge, there should not be any arbitrary barrier to accessing discharge, and the debtors' membership in a particular class also should not be a barrier to accessing discharge. The United States bankruptcy system although it is one of the most robust in the world - is not equally accessible to all debtors. Specifically, certain debtors are much more likely to enter a chapter 13 repayment plan than a chapter 7 liquidation plan, although many chapter 13 debtors never obtain debt relief, in contrast to chapter 7 debtors who gain an almost immediate discharge. ${ }^{210}$ This discrimination occurs in at least two ways: First, some jurisdictions have traditional local legal practices

\footnotetext{
209 11 U.S.C. § 1325(b) (2012).

210 Jean Braucher, Dov Cohen \& Robert M. Lawless, Race, Attorney Influence, and Bankruptcy Chapter Choice, 9 J. EMPIRICAL LEGAL STUD. 393, 394-95 (2012); Scott F. Norberg \& Andrew J. Velkey, Debtor Discharge and Creditor Repayment in

Chapter 13, 39 CREIGHTON L. REV. 473, 476 (2006); William C. Whitford, The Ideal of Individualized Justice: Consumer Bankruptcy as Consumer Protection, and Consumer Protection in Consumer Bankruptcy, 68 AM. BANKR. L.J. 397, 411 (1994).
} 
of preferring one chapter over another and steering more clients into chapter 13 plans; in effect, debtors face barriers to chapter 7 arbitrarily, by virtue of the district in which they file.211 Second, and more nefariously, empirical research shows that African American debtors are far more likely to be steered into a chapter 13 case than white debtors - even when they expressly state that they prefer a chapter 7 filing. ${ }^{212}$ In addition, debtors who benefit most from bankruptcy - those with mostly exemptible property who can protect assets such as homes and cars while discharging debt - are far more likely to be white. ${ }^{213}$ Such discriminatory patterns are inconsistent with human rights principles.

\subsection{Privacy}

Privacy is another relevant human rights consideration in the debt relief context. The ACHR, ICCPR, and ECHR all provide for freedom from arbitrary interference with privacy, home, or correspondence. ${ }^{214}$ The ACHR adds protection from "abusive" interference. ${ }^{215}$ The ACHPR does not protect the right to privacy. Under European human rights jurisprudence, the privacy protection extends to all lawful residences (including offices, campers, and holiday homes), not only homes that the individual owns as long as there is a sufficient family connection to the dwelling. ${ }^{216}$ Violations of the right to respect for private life and

211 Jean Braucher, Lawyers and Consumer Bankruptcy: One Code, Many Cultures, 67 AM. BANKR. L.J. 501, 581 (1993); Chrystin Ondersma, Are Debtors Rational Actors? An Experiment, 13 LEWIS \& CLARK L. REV. 279, 296-300 (2009).

212 Braucher, Cohen \& Lawless, supra note 211, at 400-15.

213 A. Mechele Dickerson, Race Matters in Bankruptcy Reform, 71 Mo. L. REv. 919, 930 (2006); A. Mechele Dickerson, Race Matters in Bankruptcy, 61 WASH. \& LEE L. REV. 1725, 1758-59 (2004).

214 Convention for the Protection of Human Rights and Fundamental Freedoms, supra note 101, art. 8, § 1 ("Everyone has the right to respect for his private and family life, his home, and his correspondence."); ICCPR, supra note 62, art. 17; American Convention, supra note 93, art. 11, § 2 (prohibiting "arbitrary or abusive interference" with one's "private life," home, or correspondence).

215 American Convention, supra note 93, art. 11, § 2.

216 Buckley v. United Kingdom, 23 EHRR 101, 1996-IV Eur. Ct. H.R. (Sept. 29, 1996), available at http://hudoc.echr.coe.int/sites/eng/pages/search.aspx?i=00158076 (1996) (stating that a caravan is a "home" for privacy purposes); Gillow v. United Kingdom, 11 EHRR 335, A109 Eur. Ct. H.R. (Nov. 24, 1986), available at http://hudoc.echr.coe.int/sites/eng/pages/search.aspx?i=001-57493 (observing that intention to return to a particular contested residence was sufficient to 
home include searches, ${ }^{217}$ environmental interference, ${ }^{218}$ telephone tapping, ${ }^{219}$ and failure to protect personal belongings that formed part of the home.220 Interference with privacy interests is justified if "necessary in a democratic society in the interest of national security, public safety and the economic well-being of the country, for the prevention of disorder and crime, for the protection of health and morals, or for the protection of the rights and freedoms of others. ${ }^{221}$ Finally, the right to privacy now includes the "right to be forgotten" in internet search materials; bankruptcy filings and other adverse credit information cannot be indefinitely electronically available. ${ }^{222}$

Privacy concerns intersect with debt relief measures in several

establish that it was a "home" even when traveling abroad for many years); Mentes v. Turkey, 1997-VIII Eur. Ct. H.R. (Nov. 28, 1997), available at http://hudoc.echr.coe.int/sites/eng/pages/search.aspx?i=001-58120S.

217 Chappell v. United Kingdom, A152-A Eur. Ct. H.R. (Mar. 30, 1989), available at http://hudoc.echr.coe.int/sites/eng/pages/search.aspx?i=001-57459; Funke v. France, A256-A Eur. Ct. H.R. (Feb 25, 1993), available at http://hudoc.echr.coe.int/sites/fra/pages/search.aspx?i=001-57809; Murray v. United Kingdom, A300-A Eur. Ct. H.R. (Oct. 28, 1994), available at http://hudoc.echr.coe.int/sites/eng/pages/search.aspx?i=001-57895.

218 Deés v. Hungary, App. No. 2345/06, Eur. Ct. H.R. (Nov. 9, 2010), available at http://hudoc.echr.coe.int/sites/eng/pages/search.aspx?i=001-101647; López Ostra v. Spain, Eur. Ct. H.R., A303-C Eur. Ct. H.R. (Dec. 9, 1994), available at http://hudoc.echr.coe.int/sites/eng/pages/search.aspx?i=001-57905; Powell and Rayner v. United Kingdom, A172 Eur. Ct. H.R. (Feb 21, 1990), available at http://hudoc.echr.coe.int/sites/eng/pages/search.aspx?i=001-57622.

219 Klass v. Germany, A28 Eur. Ct. H.R. (Sept. 6, 1978), available at http://hudoc.echr.coe.int/sites/fra/pages/search.aspx?i=001-57510.

220 Novoseletskiy v. Ukraine, 2005-II Eur. Ct. H.R. (Feb. 22, 2005), available at http:/ / hudoc.echr.coe.int/sites/eng/pages/search.aspx?i=001-

68373\#\{"itemid":["001-68373"]\}.

221 The European Convention on Human Rights, supra note 170, art. 8, §1.

222 See Google Spain SL, Google Inc. v. Agencia Española de Protección de Datos, Mario Costeja González, Case C-131/12, 2014 E.C.R., available at http:/ / eur-lex.europa.eu/legal-

content/EN/TXT/HTML/?uri=CELEX:62012CJ0131\&from=EN (discussing a case involving an individual bringing suit before the Court of Justice of the European Union for data retention regarding search listings mentioning unpaid social security debts, and associated rights to removal of information by operators of search engines). Although the case was a European Court of Justice case rather than a human rights case, the decision was based on the privacy rights in the Charter of Fundamental Rights in the European Union. See also Lilian Mitrou \& Maria Karyda, EU's Data Protection Reform and the Right to Be Forgotten - A Legal Response to a Technological Challenge?, 5th International Conference of Information Law and Ethics 2012, at 2, available at http:// papers.ssrn.com/sol3/papers.cfm?abstract_id=2165245. 
respects: First, debt relief regimes may provide an escape from creditor conduct that interferes with privacy infractions. For example, credit reporting and creditor data collection may raise privacy concerns. One way to satisfy this obligation would be to prohibit invasive collection practices altogether using consumer protection laws such as the U.S. Fair Debt Collection Practices Act and the Fair Credit Reporting Act, both of which incorporate privacy measures.223 Alternatively, nations could establish an insolvency regime that allows debtors to opt out of such collection practices. Second, any abusive, arbitrary, or improper separation of an individual from his or her dwelling implicates privacy concerns in addition to the property concerns discussed above. Foreclosure may result in the inability of debtors to maintain privacy; shelters or other shared living spaces may not provide sufficient private space. ${ }^{224}$ An effective insolvency regime may aid in an appropriate resolution of indebtedness that respects the debtor's right to arbitrary interference with their home.

To comply with privacy obligations, debt relief regimes should be structured in a way that is consistent with privacy rights. Court proceedings and court records should be cognizant of debtor privacy. In the case of proceedings that involve the exposing of debtors' personal information, for example, the case proceedings should be private, and debtors' personal information should be kept private. Trustees' investigations into debtors' assets and financial condition must respect privacy concerns. Insolvency proceedings also cannot be excessive in length or divert mail correspondence from the debtor for an excessive period of time.225

Finally, although an insolvency regime may be one way to protect against privacy infringement, it may not be necessary if there are sufficient privacy protections in place external to any response to over-indebtedness. Restrictions on debt collection tactics and use and publication of debtors' private information may be sufficient to satisfy privacy concerns.

22315 U.S.C. $1601, \S \S 605,804-05,808$.

224 Petition Before the European Court of Human Rights, Solorzano Verdugo v. Spain 35 (Jan. 18, 2012) (copy of petition on file with author); Brüggemann and Scheuten v. Germany, D.R. 5 Eur. Ct. H.R. 103 (1976), available at http://hudoc.echr.coe.int/webservices/content/pdf/001-74824.

225 See Luordo v. Italy, App. No. 32190/96, Eur. Ct. H.R. (Oct. 17, 2003), available at http://hudoc.echr.coe.int/sites/eng/pages/search.aspx?i=001-61231; Bottaro v. Italy, App. No. 56298/00, Eur. Ct. H.R. (Oct. 17, 2003) (Judgment) (holding that a fourteen year case violates property rights). 


\subsection{Human Dignity}

The Universal Declaration of Human Rights opens by proclaiming, "All human beings are born free and equal in dignity and rights." 226 The Preamble to the ICCPR and ICESCR both specify that the protected rights "derive from the inherent dignity of the human person." 227 The only instrument that expressly includes a right to human dignity is the African Charter on Human and Peoples' Rights, which provides: "Every individual shall have the right to the respect of the dignity inherent in a human being and to the recognition of his legal status." 228

The concept of human dignity is used to refer to two different things: first, the notion that each human being has inherent value and should not be used as a means to an end, and second, the protection against shame, humiliation, and marginalization. While many scholars and policymakers do not consider human dignity protection to require prevention of shaming and marginalization, the Council of Europe's Recommendation focused on ameliorating experiences of shame and marginalization for debtors, which suggests that this is a concern nation-states may wish to take into account when legislating responses to over-indebtedness. This section should not be read as an account of what international human rights law requires, but rather should be read as a tool for nation-states who have embraced this expansive notion of human dignity.

Over-indebtedness and the potential responses to overindebtedness raise a number of concerns relating to the protection of the debtors' human dignity. First, the condition of overindebtedness itself is often an experience of shame and marginalization. Debtors in many insolvency systems have described "pervasive and profound feelings of guilt, shame, and stigma." 229 In many cultures, the inability to manage debt

226 Universal Declaration of Human Rights, supra note 66, art. 1.

227 ICCPR, supra note 62, at pmbl.; ICESCR, supra note 81, at pmbl.

228 African Charter on Human and Peoples' Rights, supra note 112, art. 5.

229 World Bank Report, supra note 1, at 43. See generally Rafael Efrat, The Moral Appeal of Personal Bankruptcy, 20 WHITTIER L. REV. 141 (1998); Elizabeth Warren, Teresa A. Sullivan \& Jay Lawrence Westbrook, Less Stigma or More Financial Distress: An Empirical Analysis of the Extraordinary Increase in Bankruptcy 
obligations, and particularly a formal declaration of such an inability, may signal "a sort of social and economic death in many parts of the world[.]" 230 Not only is the over-indebted individual often already marginalized, but the debt collection practices for resolving this over-indebtedness may exacerbate such marginalization. Creditor collection tactics can be particularly invasive of debtors' human dignity. The experience of the debtor unable to pay for his father's cremation and having creditors return his father's body to his doorstep is one extreme example of infringement on a debtor's human dignity. 231 One debtor describes a creditor collecting an overdue cable bill who called when her spouse was on life support, saying "people get sick and die every day. That's not my problem," and, on another occasion, "You crawl, you walk, you get a bus ... you do whatever you can to get here [to make the payment.]"232

The right to an adequate standard of living is closely entwined with the right to human dignity. Stripping an individual of belonging and requiring them to labor primarily for the benefit of creditors - indefinitely - interferes with their capacity for a dignified life. 233

A system for reducing debt burdens could ameliorate some of the human dignity concerns raised here. In cases where the condition of over-indebtedness interferes with the debtor's ability to provide housing consistent with human dignity, a discharge of debt may also enable the debtor to regain dignity by becoming selfsufficient, at least in cases where reducing the debt burden leaves the individual with sufficient income to meet the basic needs of herself and her dependents. An insolvency regime may also provide an escape from humiliating debt collection practices; most insolvency regimes prohibit creditor collection activity subsequent to the filing of a petition. 234

Filings, 59 STAN. L. REV. 213 (2006)

230 World Bank Report, supra note 1, at 44.

231 Son Can't Pay, So Father's Body Is Returned, supra note 2.

232 L. Stuart Ditzen, Lawyer's Methods, Debtors' Nightmare He's Relentless, No Matter How Small the Debt. His Tactics Are All Legal, He Says., PHILly.COM (June 12, 1994), http://articles.philly.com/1994-06-12/news/25831052_1_bank-accountssteven-b-zats-bill-collector.

233 Federal exemptions of social security provide some additional protections, and federal bankruptcy exemptions are available in some states.

234 For example, in the United States and other jurisdictions, a bankruptcy filing puts in place a bar on collection activity. See 11 U.S.C. § 362 (2012). 
There are, however, limits to what insolvency can accomplish with respect to protecting or restoring debtors' human dignity. Stigmatization and marginalization will likely not be cured in an insolvency system unless the jurisdiction develops a method for ensuring that its insolvency system is capable of mitigating the shame or stigmatization associated with over-indebtedness or failure to pay debts. Indeed, many insolvency systems may risk exacerbating the shame or marginalization resulting from debtrelated woes. Some insolvency system are unnecessarily punitive and may provoke shame, particularly if the setting for resolution is a public one and particularly if bankruptcy records are made public. Some jurisdictions have explicit stigmatizing provisions for example, debtors may be precluded from becoming company directors or from traveling abroad. An example of a punitive provision in an insolvency system includes the means test in the U.S. 2005 amendments; debtors faced a presumption that they were acting "abusively" if a calculation of their disposable income was above a certain amount, without regard to whether such debtors filed for bankruptcy in good faith. ${ }^{235}$

There is also a risk that a bankruptcy filing could compound rather than relieve the sense of shame felt by over-indebted individuals, and any insolvency regime should take care to mitigate this risk. For example, the London Economics Report recommended replacing the term "bankruptcy" with something less stigmatizing such as "debt adjustment." 236 Some debtors also find the experience of attending public bankruptcy proceedings induces feelings of shame; debtors' dignity could be protected by private meetings rather than in open court. In addition, making bankruptcy filing information publicly available can also take on a shaming mechanism; this can be avoided by removing debtors' names and addresses from filing documents. To avoid infringement on debtors' human dignity, an insolvency system should not subject the debtor to shame or stigmatization.

An insolvency system is also not the only way to protect against some of the human dignity concerns raised here. For example, in jurisdictions that provide sufficient restrictions on

235 See 11 U.S.C. § 707(b) (2012) (stipulating the court may dismiss a case filed under chapter 7 of the bankruptcy code by an individual debtor whose debts are primarily consumer debts, or, with the debtor's consent, convert the case into a chapter 11 or 13 case, if the court finds abusive use of chapter 7).

236 London Economics Report, supra note 5, at xii. 
abusive collection methods and an adequate social safety net, insolvency many not add much from a human rights perspective. A London Economics report on best practices for protecting consumers in financial difficulty discussed the various types of restrictions on enforcement among European nations, and identified "common underlying principles" which, according to the report authors, demonstrated "the desire of legislators to preserve the debtor's human rights and human dignity" while also facilitating fair debt collection. The Report concluded that the protection of human dignity requires restrictions on debt collection practices. According to the report, these restrictions included: 1) ensuring sustainable minimum income, 2) ensuring access to accommodation, 3) preventing harassment, confusion or unfair duress to extract payment, 4) ensuring access to utilities, 5) protection debtors' privacy, and 6) ensuring collection charges are born by lenders. ${ }^{237}$ (Several of these concerns implicate other human rights that the report did not address, but that I have discussed in the preceding subsections of this Part).

If the debtor does not face abusive collection methods and is provided with food and housing that preserve dignity, and there are no issues of social exclusion or shame, an insolvency regime resulting in debt discharge may not be required to satisfy human rights concerns. On the other hand, if there is no social safety net, a robust insolvency regime may protect against infringement on human dignity; for example, where an inability to service debt would otherwise lead to housing conditions inconsistent with human dignity, the ability to obtain debt relief and a "fresh start" may protect human dignity - at least where the cause of the inability to meet basic needs is primarily due to overindebtedness. 238

\section{CONSUMER BANKRUPTCY EXAMPLES: PROPERTY RigHTS AND THE RigHT TO DUE PROCESS}

The preceding Part provided an exploration of the implications

237 Id. at xvi.

238 Of course, the cause is seldom exclusively over-indebtedness - income reduction due to medical expenses, job loss, or family break-up often initially causes over-indebtedness, and the cycle of over-indebtedness further reduces the debtor's ability to make ends meet. 
of specific human rights with respect to efforts to address overindebtedness. This Part provides a more in-depth analysis of the right to property and the right to due process and their implications for the response to over-indebtedness. In crafting debt relief measures, nations must be cognizant not only of debtors' property and due process rights, but also of creditors' property and due process rights. This Part examines specific issues that can arise in each context: with respect to property rights, it considers the modification of rights of secured creditors, and with respect to process rights, it considers the resolution of debtors' affairs in an administrative rather than judicial context.

\subsection{Property Rights}

The human right to property has particularly interesting implications because both creditors and debtors have property rights that responses to over-indebtedness should take into account. Modifications of secured creditors' rights under an insolvency regime or otherwise may raise property right concerns. In fact, there have already been instances of secured creditors suing based on property right deprivations under human rights law. ${ }^{239}$ Debtors also have rights to property that any insolvency regime seeking to account for human rights principles would need to address. This Section first explores the right to property generally, then addresses the property rights of debtors and creditors, and then specifically considers the issue of modification of secured creditors' rights in an insolvency regime.

\subsubsection{The Human Right to Property Generally}

Property rights ${ }^{240}$ are protected in several human rights

\footnotetext{
239 Wilson v. Sec'y. of State for Trade \& Indus. (Appellant), [2003] UKHL 40, 1 (H.L.) (appeal taken from Eng.), available at http://www.publications.parliament.uk/pa/ld200203/ldjudgmt/jd030710/will1.htm; Wilson v. First Cnty. Trust Ltd., [2003] UKHL 40.

240 The Right to Property, ICELANDIC HUM. RTS. CTR., available at http://www.humanrights.is/the-human-rights-

project/humanrightscasesandmaterials/humanrightsconceptsideasandfora/subst antivehumanrights/therighttoproperty/.
} 
instruments. ${ }^{241}$ Property rights are not enshrined in either the International Covenant on Civil and Political Rights or the International Covenant on Economic, Social and Cultural Rights, even though Article 17 of the Universal Declaration of Human Rights provides for the "right to own property" and asserts and that "[n]o one shall be arbitrarily deprived of his property." 242 In addition, while the right to property is not enforced by any U.N. body, the ECHR, the ACHR, and the ACHPR each protect the right to property. 243 Article 1 of the first Protocol to the ECHR provides: "Every natural or legal person is entitled to the peaceful enjoyment of his possessions. No one shall be deprived of his possessions except in the public interest and subject to the conditions provided for by law and by the general principles of international law." 244 Article 21 of the ACHPR also provides for the right to "use and enjoyment" of property, but specifies that such right can be subordinated to "the interest of society." 245 Deprivation of property is permitted only upon "just compensation" and only "for reasons of public utility or social interest ... according to the forms

One of the more controversial and complex human rights is the right to property. The right is controversial because the very right which is seen by some as central to the human rights concept is considered by others to be an instrument for abuse, a right that protects the 'haves' against the 'have-nots'. It is complex, because no other human right is subject to more qualifications and limitations and, consequently, no other right has resulted in more complex case-law of, for instance, the supervisory bodies of the ECHR. It is complex also because it is generally regarded as a civil right, and by some even as an integrity right. At the same time, it clearly has characteristics of social rights with significant implications for the distribution of social goods and wealth. Moreover, the right to property has major implications for several important social and economic rights such as the right to work, the right to enjoy the benefits of scientific progress, the right to education and the right to adequate housing. Id.

241 See generally Ursula Kriebaum \& Christoph Schreuer, The Concept of Property in Human Rights Law and International Investment Law, in HUMAN RIGHTS, DEMOCRACY AND THE RULE OF LAW: LibER AMICORUM LUZIUS WiLDHABER 743, 757 (Stephan Breitenmoser et al. eds., 2007).

242 The Universal Declaration of Human Rights, supra note 66, art. 17.

243 The European Convention on Human Rights, supra note 170, art. 1; American Convention, supra note 93, art. 21; African Charter on Human and Peoples' Rights, supra note 112, art. 14. In addition, of course, many nations' constitutions protect property rights as well. See, e.g., U.S. CONST. amend. X.

244 The European Convention on Human Rights, supra note 170, art. 1.

245 African Charter on Human and Peoples' Rights, supra note 112, art. 21.1. 
established by law."246 In addition, section 21 of the ACHPR specifically prohibits usury and "any other form of exploitation of man by man." 247 The placement of the usury prohibition in the context of section 21 suggests a limitation on the scope of property rights that one can acquire. ${ }^{248}$

The European system and Inter-American system have developed a relatively broad concept of property under human rights jurisprudence. Under EU human rights law, "possessions" include both existing possessions and possessions in which an individual has a "'legitimate expectation' of obtaining effective enjoyment of a property right." 249 Future income can even be a property interest if an individual has an "enforceable claim" to the income.250 Moreover, if a national law provides for welfare payments as a matter of right, the payments are property interests protected by Article 1.251 Claims are considered "assets" in the nature of property only if domestic law considers such claims to be

246 Id.

247 Id. art. $21, \S 3$.

248 The ACHR is the only human rights instrument to include a usury prohibition; however, in spite of the prohibition, most member states do not in fact ban usury.

249 Gratzinger and Gratzingerova v. Czech Republic, 2002-VII Eur. Ct. H.R. 399 (July 10, 2002) (Grand Chamber), available at http://hudoc.echr.coe.int/sites/eng/pages/search.aspx?i=001-22710; Kopecky v. Slovakia, App. No. 44912/98, 2004-IX Eur. Ct. H.R. 125, 144 (Sept. 28, 2004), available at http://hudoc.echr.coe.int/sites/eng/pages/search.aspx?i=001-66758 (citing Prince Hans-Adam II of Liechtenstein v. Germany, App. No. 42527/98, 2001-XIII Eur. Ct. H.R. (July 12, 2001), available at http://hudoc.echr.coe.int/sites/eng/pages/search.aspx?i=001-59591).

250 Anheuser-Busch Inc. v. Portugal, App. No. 73049/01, 45 Eur. H.R. Rep. 36 [830], 849 (Jan. 11, 2007) (Grand Chamber), available at http://hudoc.echr.coe.int/sites/eng/pages/search.aspx?i=001-78981; Ian Edgar (Liverpool) Ltd. v. United Kingdom, App. No. 37683/97, Eur. Ct. H.R. (Jan. 25, 2000), available at http://hudoc.echr.coe.int/sites/eng/pages/search.aspx?i=0015035; Levänen v. Finland, App. No. 34600/03, Eur. Ct. H.R. (Apr. 11, 2006), available at http://hudoc.echr.coe.int/sites/eng/pages/search.aspx?i=001-75390; Wendenburg v. Germany, 2003-II Eur. Ct. H.R. (Feb. 6, 2003), available at http://hudoc.echr.coe.int/sites/eng/pages/search.aspx?i=001-23337.

251 Andrejeva v. Latvia, App. No. 55707/00, Eur. Ct. H.R. (Feb. 18, 2009), available at http://hudoc.echr.coe.int/sites/eng/pages/search.aspx?i=001-91388; Moskal v. Poland, App. No. 10373/05, Eur. Ct. H.R. (Sept. 15, 2009), available at http://hudoc.echr.coe.int/sites/eng/pages/search.aspx?i=001-94009 S 38; Stec v. United Kingdom, App. Nos. 65731/01, 65900/01, 2006-VI Eur. Ct. H.R. 131 (Apr. 12 , 2006), available

http://hudoc.echr.coe.int/sites/eng/pages/search.aspx?i=001-73198. 
property assets. ${ }^{252}$ Creditors have a property interest at the moment when their claims are "sufficiently established to be enforceable." 253 The Inter-American Court has defined right to property as protecting 'those material things which can be possessed, as well as any right which may be part of a person's patrimony; that concept includes all movables and immovables, corporeal and incorporeal elements and any other intangible object capable of having value.'"254 Property rights can include public benefits in the Inter-American system; in one case the reduction in pensions of public employees was found to be a violation of the right to property. ${ }^{255}$

\subsubsection{Creditors' and Debtors' Property Rights}

Considering the property interests of creditors and debtors requires a two-step analysis: first, what is the nature of the property interest at stake, and second, does the public interest permit deprivation of this interest?

Property rights issues are particularly salient in the secured credit context. Where the debt at issue is a secured debt - that is, where the creditor retains the right to repossess a specific item of the debtor's collateral upon default - the possessory property interest of the debtor and the contingent property right of the secured creditor will collide. Secured creditors have possessory and title rights that are contingent upon default. Under human

252 Anheuser-Busch Inc. v. Portugal, App. No. 73049/01, 45 Eur. H.R. Rep. 36 [830], 849 (Jan. 11, 2007) (Grand Chamber); Kopecky v. Slovakia, App. No. 44912/98, 2004-IX Eur. Ct. H.R. 125 (Sept. 28, 2004); Eskelinen v. Finland, App. No. 63235/00, Eur. Ct. H.R. (April 19, 2007), available at http://hudoc.echr.coe.int/sites/eng/pages/search.aspx?i=001-80249; Plechanow v. Poland, App. No. 22279/04, Eur. Ct. H.R. (July 7, 2009), available at http://hudoc.echr.coe.int/sites/eng/pages/search.aspx?i=001-93302.

253 Burdov v. Russia, App. No. 59498/00, Eur. Ct. H.R. (May 7, 2002), available at http://hudoc.echr.coe.int/sites/eng/pages/search.aspx?i=001-60449; Stran Greek Refineries v. Greece, App. No. 13427/87, Eur. Ct. H.R. (Dec. 9, 1994), available at http:/ / hudoc.echr.coe.int/sites/eng/pages/search.aspx?i=001-57913.

254 Mayagna (Sumo) Awas Tingni Cmty. v. Nicaragua, Inter-Am. Ct. H.R. (ser. C) No. 79 (Aug. 31, 2001), available at http://www1.umn.edu/humanrts/iachr/AwasTingnicase.html.

255 Torres Benvenuto et al. v. Peru (Five Pensioners Case), Inter-Am. Ct. H.R. (Feb. 28, 2003), available at http://www.corteidh.or.cr/docs/casos/articulos/seriec_98_ing.pdf. 
rights principles, however, deprivation of either property interest is permitted if such deprivation is in the public interest. For example, human rights authorities have found consumer protection policies to serve the public interest and justify limitations on creditors' claims. ${ }^{256}$

To undertake this analysis, we first need to understand the scope of the property right, remembering that the state is entitled to determine the scope of the property rights in the first place. The boundaries of debtors' and creditors' property rights will be determined ex ante by a combination of contract principles and domestic law, and will include whatever expansion of those property rights an insolvency filing triggers. So we ask: What property right(s) are permitted to come into existence? By way of example, in the U.S., non-possessory non-purchase-money security interests in household goods are prohibited. ${ }^{257}$ Consequently, no property interest in such collateral can come into existence, and modification of those contracts could never interfere with the creditor's property rights. For nations with insolvency systems, property rights also include whatever expansion or contraction that the insolvency filing system - existing at the time of contract permits.

With respect to debtors' property interests, debtors may have contractually agreed to relinquish their property rights in the collateral upon default. However, domestic law can and often does protect debtors from fully waiving, at the contractual stage, their property rights upon default. Debtors are typically given time to cure and prevent foreclosure of their property interest, ${ }^{258}$ and initiation of a formal insolvency proceeding can further enhance the debtors' property interests by providing for additional time to cure and providing a forum for modifying the contract. ${ }^{259}$

256 Wilson v. First Trade Cnty. Trust Ltd. [2003] UKHL 40, [2003] 4 All E.R. 97, 130-31 (U.K.) (Hope, L.J.) [hereinafter Wilson].

257 Federal Fair Debt Collection Practices Act (FDCPA), 15 U.S.C. §§ 16921692 p (2012).

258 Foreclosure Report: Survey of State Foreclosure Laws, NAT'L CONSUMER L. CTR., available foreclosure laws in each state).

259 See, e.g., 11 U.S.C. § 1322(b)(5) (2012) (stating bankruptcy plan may "provide for curing of any default within a reasonable time and maintenance of payments while the case is pending"). 
Foreclosure consistent with the debtor's established property rights will not interfere with the debtors' human right to property, although foreclosure may certainly implicate other human rights concerns, such as the debtor's human dignity or right to adequate shelter and other basic needs. This analysis will ultimately depend, among other things, on the housing that would be available to the debtor should his/her home be required to be relinquished. An example of foreclosure legislation potentially incorporating debtors' human rights concerns is the U.K. Insolvency Act, which prevents foreclosure in "exceptional circumstances." 260 Some have argued that Human Rights Act requires "exceptional circumstances" to include "all instances where the family home and rights of children are in issue." 261 Legislatures may also choose to protect debtors' equity interests in the family home by exempting the family home from collection. ${ }^{262}$ However, the debtor's interest in their home will often conflict with the secured creditor's property rights.

Whether the secured creditor's property right is the right to the collateral or something else (e.g., the right to the value of the collateral - or something less than the value of the collateral) depends upon whether the law at the time of the contract enforces repossession rights or allows for the creditor's right to be satisfied by another means; for example, payment of the value of the collateral.

Insight into the scope of creditors' property rights under a human rights framework can be found in Wilson v. First County Trust. Wilson is a U.K. case brought under the Human Rights Acts, which gives the ECHR the power of domestic enforcement.263 The case demonstrates how creditors may claim that new debt relief

260 UK Insolvency Act 335(A)(3).

261 Helene Pines Richman, Using the Human Rights Act to Save the Family Home, available

http://www.9stonebuildings.com/publications/human_rights.pdf (last visited Jan. 25, 2014).

The Human Rights Act 1998 has the potential to redefine a bankrupt's family's rights, and to possibly save the family home. It applies to dealings between private individuals through the duty of public authorities, including courts and tribunals, not to act in a way which is incompatible with Convention rights and to protect individuals against breaches of their rights (section 6(1) of the Human Rights Act 1998).

262 World Bank Report, supra note 1, at 80.

263 Wilson, supra note 259, ๆ 10. 
legislation may impair their property interests. In Wilson, a pawnbroker's loan was originally deemed unenforceable under the Consumer Credit Act of 1974 because it incorrectly stated loan terms. ${ }^{264}$ However, the Secretary of State appealed, fearing that the Consumer Credit Act, in rendering such loans unenforceable, violated the First Protocol, providing for right to peaceful enjoyment of one's possessions. ${ }^{265}$ As discussed, the First Protocol provides that deprivation of possessions is permitted only "when in the public interest," and states that the preclusion of such deprivation "shall not ... in any way impair the right of a State to enforce such laws as it deems necessary to control the use of property in accordance with the general interest..."266 Thus, under the European Convention, property deprivation is permitted if necessary for the "public interest" or "general interest." 267

The members of the Court found no violation of the First Protocol, but differed in their reasoning. Lord Nicholls concluded that the lack of enforcement of the credit agreement was indeed a "deprivation of possessions." 268 On the other hand, he reasoned that such a deprivation was permissible as a "legitimate exercise in consumer protection." 269 He articulated that the Consumer Credit Act constituted a "legitimate exercise in consumer protection" because 1) the legislation served the "public interest" and 2) the legislation was a "proportionate means by which to solve a social problem." 270 Nicholls concluded that although the legislation may "involve the compulsory transfer of property from one person to another," ${ }^{271}$ such deprivation was permissible because " $\left.\mathrm{t}\right]$ here is a public interest in protecting [people who want to borrow money]

264 Id. ๆ $1,3$.

265 Id. I 8. The Secretary also brought a claim under Article 6 of the Convention for the Protection of Human Rights and Fundamental Freedoms (as incorporated into U.K. law in the 1998 Human Rights Act), providing for right to a fair trial. Id. 9 . The House of Lords rejected the Article 6 claim, holding that the Consumer Credit Act's rendering noncompliant credit agreements unenforceable was a "limitation on the substantive scope of creditor's rights" rather than a circumscription of proper judicial procedure. Id. \ 37.

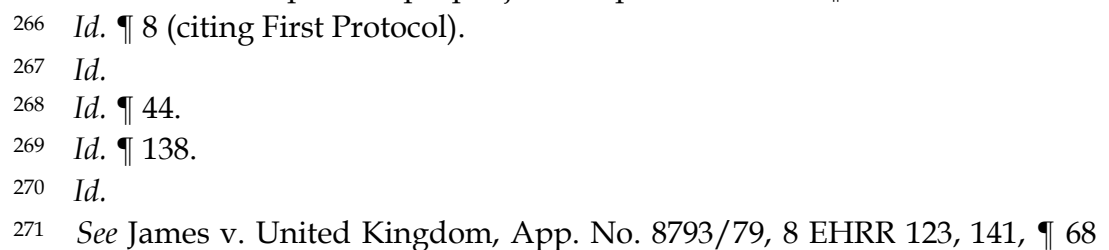
(Feb. 21, 1986). 
from exploitation." 272 With respect to the proportionality holding, Nicholls found that "[t]he means chosen to cure the social mischief [was] appropriate and not disproportionate in its adverse impact." 273 Nicholls expressed a willingness to defer to the legislature on "matters of broad social policy," 274 and determined that it was sufficient for a finding of proportionality that Parliament considered creditors' Convention rights. ${ }^{275}$ Parliament's consideration of and rejection of alternative sanctions was sufficient to show that it considered creditors' property rights. ${ }^{276}$

Lord Hope and Lord Scott, in contrast to Lord Nicholls, reasoned that article 1 of the First Protocol was not engaged because the pawnbroker lacked a property right. ${ }^{277}$ That is, the Consumer Credit Act prevented [the pawnbroker] from ever obtaining a property right against Wilson. Scott reasoned:

[A]rticle 1 of the First Protocol is directed to interference with existing possessions or property rights. [The pawnbroker] never had, at any stage in the history of the loan agreement, the right to enforce against Mrs. Wilson the repayment of the $£ 5000$. Neither the 1974 Act as a whole nor section 127(3) in particular constituted an interference with a preexisting right of [the pawnbroker] to enforce repayment by Mrs. Wilson of the $£ 5000$. The Act, and section 127(3) prevented [the pawnbroker] from ever possessing that right. ${ }^{278}$

Hope and Scott suggested that, had the legislation been enacted after the loan had already been made, the pawnbroker's property

272 Wilson, supra note 257, 168.

$273 \quad$ Id. 962.

274 Id. 70. This reasoning is based in the ECHR doctrine of the "margin of appreciation" which provides deference to states on unsettled questions of human rights policy. See generally Steven Greer, The Margin of Appreciation: Interpretation and Discretion Under the European Convention on Human Rights, 17 HUM. RTS. FILES 1, 7-13, available at http://www.echr.coe.int/LibraryDocs/DG2/HRFILES/DG2EN-HRFILES-17\%282000\%29.pdf.

275 Wilson, supra note 257, 975.

$276 \quad$ Id. 972.

277 Id. 9108.

$278 \quad$ Id. $\ 168$. 
rights may have been implicated. However, this does not mean that a human rights violation would have been held to occur; in that case the legislature would need to demonstrate that the deprivation was necessary for the public interest, a condition that Lord Nicholls found to be met in this instance in any event.

The foregoing analysis provides two helpful insights for the response to over-indebtedness and the creation of new insolvency regimes. First, new legislation that impairs existing creditors property interests may raise human rights concerns. This does not mean that the legislation cannot be enacted without violating creditors' property rights. All that is required is that the legislature considers creditors' property rights and attempt to identify alternatives. In fact, Wilson indicates that explicit consideration of creditors' property interests may not be necessary; however, it may help prevent suits being filed. The second takeaway is that for new creditors - creditors whose claims arise after the passage of new legislation - there will not be a property deprivation claim because the national legislation determines the boundaries of existing property rights. 279 That is, if national legislation proclaims that a private contract is unenforceable it cannot give rise to a property right in the first instance.

\subsubsection{Property Rights Compliant Insolvency Regimes}

Creation of an insolvency regime or certain changes to an existing insolvency regime may implicate the property rights of creditors or debtors. This does not mean, however, that changing the law would be impermissible from a human rights standpoint.

Insolvency laws generally are not considered to violate debtors' peaceful enjoyment of their possessions; however, if the insolvency proceedings are too long in duration, they may constitute impermissible control of debtors' property. ${ }^{280}$ The European Court

279 For an analysis of bankruptcy law from the lens of the constitutional right to property, see Jonathan C. Lipson, Debt and Democracy: Towards a Constitutional Theory of Bankruptcy, 83 Notre DAME L. REV. 605, 660-69 (2008).

280 See Bottaro v. Italy, App. No. 56298/00 (Oct. 17, 2003) (Judgment) (showing that twelve year insolvency proceedings violate property rights); Luordo v. Italy, App. No. 32190/96, Eur. Ct. H.R. (Oct. 17, 2003), \『 68-71, http://hudoc.echr.coe.int/sites/eng/pages/search.aspx?i=001- 
of Human Rights has found violations in the context of two business insolvency proceedings (finding 12 and 14 years to be excessive control of debtors' property in violation of Article 1, Protocol 1). ${ }^{281}$ There is no reason to think that the same analysis would not apply to consumer proceedings.

With respect to insolvency laws that change creditors' rights, new laws would not raise property concerns for contracts going forward because it would be a limit on the property right that is permitted to come into existence. Second, even with respect to existing contracts, deprivation of property rights is permissible on public interest grounds. ${ }^{282}$ For example, after the Finnish insolvency laws were reformed, existing creditors brought a case in the European Court of Human Rights, arguing that the insolvency law interfered with their property rights under Article 1, Protocol 1.283 The Court, however, held that interference with the applicant's property rights was justified because the legislation served legitimate social and economic policies and the burden on the creditor was not excessive. ${ }^{284}$ Still, the Court retained the possibility of concluding that "irrevocable extinction of a debt" would be an excessive burden on existing creditors. ${ }^{285}$

With respect to contracts going forward, if the secured creditor is entitled to a lesser property right than the interest for which they contracted, the property right is not what was contracted for but rather what the insolvency regime guarantees the creditor. For example, under the U.S. Bankruptcy Code the property right of a creditor who takes a security interest in most kinds of personal property is limited to the value of the collateral - not the collateral itself - despite what the contract indicates. A number of liens can be stripped in U.S. bankruptcy proceedings, including unperfected security interests, many judgment liens, and, in some jurisdictions,

\footnotetext{
61231\#\{"itemid":["001-61231"]\} (demonstrating that fourteen year insolvency proceedings violate property rights).

281 Id.

282 European Convention on Human Rights, Convention for the Protection of Human Rights and Fundamental Freedoms, art. 1, available at http://www.echr.coe.int/Documents/Convention_ENG.pdf (last visited Jan. 25, 2014); American Convention, supra note 93, art. 21.

283 Bäck v. Finland, App. No. 37598/97, 2004-VIII Eur. Ct. H.R., ๆ 37 (Oct. 20, 2004), available at http://hudoc.echr.coe.int/sites/eng/pages/search.aspx?i=00161929.

$284 \quad I d .9$ ๆ $50-62$.

$285 \quad$ Id. 963.
} 
junior mortgages for which the value of the collateral at the time of filing is insufficient to satisfy any portion of the debt.286 Modification of the secured creditor's contract will thus not be a property deprivation as long as the secured creditor's interest in the value of the collateral is respected. If no value is available, there is no property interest, and there can be no deprivation.

In the mortgage context, the property rights of a holder of a residential mortgage that is the debtor's primary residence are larger than the property right of an investor. The mortgage cannot be modified if it is a mortgage on a primary residence. Thus, the lender is guaranteed the collateral itself, whereas if the property is an investment property, the debtor can elect to modify the mortgage so that payments are reduced to the value of the collateral rather than the contractual payments agreed upon. ${ }^{287}$ The latter lender's property right is thus not the collateral itself but only the value of the collateral.

At the time of entering into the secured credit relationship with the debtor, the secured creditor is aware of the boundaries of any property right he will acquire in debtor's property, and thus cannot complain of a property right violation if the debtor uses insolvency proceedings to modify the secured creditor's claim. Modification of residential mortgages may raise property rights concerns. However, for mortgages that come into existence after the change to the insolvency regime, this will not be an issue. Such lenders' rights may be limited to the value of the collateral or whatever value the default regime determines. More importantly, existing mortgages can also be modified consistent with human rights concerns as long as such modification is in the public interest. In other words, one insight to be gleaned from evaluation of insolvency regimes in light of secured creditors' property rights in a human rights framework is that secured creditors' claims are not sacrosanct.

This does not mean that there will not be impediments under national law (such as constitutional property rights) 288 that may

28611 U.S.C. $\S 1325$ (2012).

28711 U.S.C. § 1322(b) (2012).

288 See generally Charles Tabb, The Bankruptcy Clause, The Fifth Amendment, and the Limited Rights of Secured Creditors in Bankruptcy, American Bankruptcy Institute Symposium on Chapter 11 Reform 2014 (arguing that U.S. bankruptcy law has mistakenly been required to comply with Takings Clause when modifying rights of secured creditors). 
need to be addressed, but human rights principles will not be a barrier to an insolvency regime that modifies secured creditors' claims. In evaluating competing property interests on public interest grounds, legislatures may need to consider when public interest weighs in favor of possessory rights and when it weighs in favor of secured lenders or landlords. On the one hand, homelessness is a serious social problem that may have spiraling deleterious consequences. For example, the prevention of homelessness is thus a legitimate public interest goal. If foreclosure or eviction is shown to lead to homelessness, this is a serious public interest concern that legislatures are empowered to address consistent with human rights standards. For instance, a change in the U.S. mortgage laws to permit modification of mortgage holders' secured claims in bankruptcy proceedings could properly have been defended as necessary to prevent homelessness, poverty, and even macroeconomic distress. ${ }^{289}$ Furthermore, foreclosures are also often associated with disruptions to children's schooling and thus, can also interfere with the debtor's children's right to an education - not only a public interest concern but also a human rights concern under the ECHR. ${ }^{290}$

It should be noted that domestic law may provide narrower grounds for interference with property rights than human rights law. The U.S. Supreme Court, for example, has stated that bankruptcy laws shall not be "construed to eliminate property rights which existed before the law was enacted in the absence of an explicit command from Congress." 291 While not described as

289 After the crisis, U.S. lenders refused to timely recognize the sharply diminished value of home loans on their books. If borrower payments could have been reduced to reflect the actual value of their homes, they may have been able to remain in their homes and service most of the debt. This would have directly benefited banks, and would have also lessened the blow to the real economy with fewer borrowers losing their homes to foreclosure and fewer housing-related job losses. World Bank Report, supra note 1, at 28. If regulations permit financial institutions to reflect a misleadingly optimistic view of account values, overvaluation can drag on and become exacerbated, "and by the time when the reality of the value-destroying insolvency is acknowledge, it is too late to avoid serious disruptions reverberating far beyond the creditor's own balance sheet[.]" Levitin, supra note 33, 585 (2009).

290 European Convention on Human Rights, supra note 170, at Protocol, art. 2.

291 United States v. Sec. Indus. Bank, 459 U.S. 70, 82 (1982). For an in-depth analysis of U.S. constitutional property rights and bankruptcy, see Lipson, supra note 282. 
permitting deprivation of property rights on the grounds of public interest, the opinion suggests that Congress has the discretion to eliminate property rights of secured creditors, even retroactively. Contrary to this, other cases suggest that retroactive lien avoidance would constitute a taking and would require compensation. ${ }^{292}$

The property example again illuminates the extent to which the response to over-indebtedness will depend on background rules: to satisfy human rights standards, existing property rights must be respected, but property rights will have been determined ex ante by the nation crafting the insolvency regime. The right to property, from a human rights view, does not create property rights, it merely protects existing property rights.

\subsection{The Right to Due Process}

\subsubsection{Due Process Rights as Human Rights Generally}

Human rights instruments require a fair trial to determine matters concerning rights or obligations; this includes both debtors' and creditors' property interests and privacy concerns. ${ }^{293}$ The ACHR, ECHR, and ICCPR all include rights to prompt and fair trials conducted by an "independent and impartial tribunal." 294

292 Armstrong v. United States, 364 U.S. 40, 46 (1960) (avoiding a lien retroactively has "every possible element of a Fifth Amendment taking.").

293 World Bank Report, supra note 1, at 50.

294

Every person has the right to a hearing, with due guarantees and within a reasonable time, by a competent, independent, and impartial tribunal, previously established by law, in the substantiation of any accusation of a criminal nature made against him or for the determination of his rights and obligations of a civil, labor, fiscal, or any other nature.

American Convention, supra note 93, art. 8, § 1. "In the determination of his civil rights and obligations ... . everyone is entitled to a fair and public hearing within a reasonable time by an independent and impartial tribunal established by law." Convention for the Protection of Human Rights and Fundamental Freedoms, supra note 101, art. 6.

The ICCPR also requires a "fair and public hearing by a competent, independent, and impartial tribunal established by law" in the determination of rights and obligations. ICCPR, supra note 62, art. 14. 
The ACHR and ICCPR additionally require that the tribunal be "competent."

\subsubsection{Debtors' and Creditors' Due Process Rights}

Under human rights principles, both debtors and creditors have the right to have their protected human rights and other civil rights and obligations determined by an independent, impartial, and competent tribunal. This includes property rights as well as contractual obligations. ${ }^{295}$ Hence, creditors attempting to enforce their contractual rights must give debtors the right to defend against accusations of default in the context of a human rights compliant tribunal. In addition, the right to due process may be violated if the judiciary is enforcing laws that violate human rights, including contract clauses that are discriminatory.296 Creditors, however, are equally entitled to protection from a human rights perspective. Consequently, creditors should have the opportunity to assert their contractual and property rights before an independent, impartial, and competent tribunal. Some of the discrimination concerns raised above may also play a role in the due process context as equal protection concerns. If the law provides different treatment to different classes of individuals with no rational basis for the distinction, such as arbitrarily inferior remedies for debtors as opposed to creditors, debtors' due process rights may not be satisfied.

\subsubsection{Respecting Debtors' and Creditors' Due Process Rights in Insolvency Regimes}

Some countries have trended toward resolving insolvency proceedings via an administrative rather than a judiciary process. The London Economics report noted that administrative resolution of debt seems to be more affordable and accessible. ${ }^{297}$ However, to

295 See Migreurop, Demanda Al Tribunal Europeo de Derechos Humanos, available at http://www.migreurop.org/article2300.html?lang=fr. See generally Petition Before the European Court of Human Rights, Verdugo v. Spain 35 (Jan. 18, 2012) (copy of petition on file with author).

296 Id.

297 London Economics Report, supra note 5, at 12. 
the extent any human right - including secured creditors' or debtors' property rights, for example - is determined in insolvency proceedings, the right to due process may require a tribunal as opposed to administrative proceedings. The London Economics report asserted that if lender responsibility for insolvency is acknowledged and consumer protection is accepted as an overriding concern, the need for judicial involvement can be rejected.298 However, this may not satisfy human rights requirements. For example, if secured creditors' property rights or debtors' property rights are resolved or determined in bankruptcy court, it may be necessary that the tribunal be "independent and impartial." 299 That said, it is important to remember that the right to property is only as expansive as background rules permit it to be. Therefore, a movement from a judicial insolvency regime to an administrative insolvency regime may prove problematic for existing claims but not for new security interests. After an administrative regime was implemented, secured creditors would be aware that their claim is subject to determination in administrative proceedings should the debtor become insolvent and choose to access the regime. Put in another way, the scope of their property interest is determined in part by potential resolution in administrative proceedings.

Insolvency regimes can also be a method for protecting debtors' procedural rights where the civil judicial system has proven inadequate. For example, unreasonable delays in proceedings involving property or privacy rights may interfere with the process rights protected in these instruments. In New York City, lenders are notorious for dragging out foreclosure proceedings and for refusing to engage in good faith settlement procedures as required.300 Bankruptcy provides an alternative forum for addressing mortgage defaults, and may aid in satisfying debtors' due process rights.

As discussed, this analysis illuminates the role of background rules in crafting a human-rights-compliant response to overindebtedness. Whether an administrative system is appropriate

298 Id.

299 ICCPR, supra note 62, art. 14.

300 MFY Legal Services, JUSTICE UNSETTLED: How the Foreclosure Shadow Docket \& Discontinuances Prevent New Yorkers from Saving Their Homes (May 2012), available at http://www.mfy.org/wp-content/uploads/Justice-Unsettled-plusAPP.pdf. 
depends upon what property and contractual rights default rules have established. Human rights instruments do not guarantee any specific contract or property. Rights such as free speech and freedom from discrimination are promised, and the right to due process requires proper adjudication of these rights, but it is not the human rights system that brings into existence specific contractual or property rights. Rather, once a nation has established the scope of its citizens' property and contractual rights, these rights are to be enforced by a fair, impartial, and competent tribunal.

\section{INSIGHTS FOR POLICYMAKING AROUND OVER-INDEBTEDNESS}

Having examined specific human rights and the link between these specific rights and nations' efforts to address overindebtedness, I now offer a few over-arching considerations that should inform policymaking around over-indebtedness to the extent human rights concerns are taken into account. The first key takeaway is that those seeking to harmonize responses to overindebtedness in a way that reflects human rights concerns should acknowledge that a one-size-fits-all approach may not be appropriate given different default rules and policy preferences. A human rights based evaluation of nations' insolvency systems or lack thereof must be contextualized in nations' background rules including: 1) the available social safety net, 2) the nature of consumer credit contracts that default laws permit to exist, and 3) permissible collection methods. The U.S., with its weak social safety net, robust consumer credit apparatus, and aggressive credit collection strategies needs a robust debt relief system from a human rights perspective. Second, a formal, legal debt relief system may not be the optimal solution for social or cultural reasons external to the default legal regime. For instance, informal or social solutions may be preferable (or at least complementary), particularly where legal systems are ineffectual. Finally, if an insolvency regime is determined to be the best method or the necessary method of ensuring that human rights obligations or principles are satisfied, the relief provided must be effective. If the relief the insolvency regime purports to provide is not in fact accessible or available to all debtors who need it, it will fail as a tool for satisfying human rights goals. 


\subsection{Contextualizing the Evaluation of Responses to Over- Indebtedness}

A human rights informed response to over-indebtedness should take into account at least three aspects of nations' legal and regulatory frameworks external to their response to overindebtedness. First, whether and what type of insolvency relief is necessary from a human rights perspective depends on the safety net that is available to debtors outside the insolvency regime. Second, the appropriate response to over-indebtedness depends upon the limitations that nations impose upon the types of debt relationships that are permitted to come into existence. Third, the proscribed method of resolving cases of over-indebtedness will vary depending upon limitations nations set on creditors' collection activities, including how much of the debtors' assets and income are permitted to be seized, and the circumstances under which such seizure can occur.

\subsubsection{Available Social Safety Net}

Whether human rights principles require an insolvency regime to treat over-indebtedness, and whether these principles require the system to contain specific features (such as access to prompt discharge) depends upon what other methods of support a nation makes available to debtors. Nations with robust social safety nets; that is, those that provide sufficient funding to ensure that individuals have access to housing, food, and healthcare, may not need an insolvency regime to comply with human rights obligations or standards. If indebted individuals are assured food, housing and access to medical treatment even if creditors are consuming much of their disposable income, their human rights may be intact despite heavy debt loads. Nations can draw their own policy conclusions regarding whether creditors or taxpayers should bear the cost of satisfying the debtor's subsistence needs. Nations that have chosen not to guarantee access to adequate food, housing, or healthcare may be more in need of a well-developed debt relief system. 
The United States does not provide the level of social support for its citizens that most European countries provide; housing, food, and unemployment subsidies are much lower per capita in the United States.301 Yet even with the 2005 restrictions to accessing debt relief, the U.S. continues to have one of the most consumer-debtor friendly insolvency regimes in the world. Most consumer debtors are - on paper - eligible for almost immediate discharge of consumer debt, assuming they are willing to relinquish any non-exempt assets. ${ }^{302}$ This does not mean that the U.S. provides the most support for debtors overall. The inverse relationship between robustness of the social safety net and robustness of the debt relief regime may not be accidental. The relationship may reflect a policy choice to satisfy obligations to citizens in different ways - through taxpayer funded subsidies or through what amount to levies on creditors. In turn, some argue, this has also increased costs to consumers, although studies have not so far proven that increased debt relief results in higher credit costs. ${ }^{303}$ For countries with limited social safety nets, like the United States, the insolvency regime may be a crucial component of satisfying human rights obligations or complying with human rights principles whereas in other countries the insolvency regime will play a minor role.

Of course, an insolvency regime cannot be a complete substitute for a social safety net from a human rights perspective. Debt relief will only aid in satisfying human rights obligations where the violation is caused by over-indebtedness and can be removed by relieving debt. An insolvency regime will not augment the human rights of impoverished but not indebted citizens who lack access to basic needs and whose dignity rights may be imperiled.

It is also important to note that a robust social safety net alone

301 Marcus Walker \& Roger Thurow, U.S., Europe Are an Ocean Apart on Human Toll of Joblessness, WALL ST. J. (May 7, 2009, 12:01 AM), http://online.wsj.com/news/articles/SB124155150793788477.

30211 U.S.C. $\S 707$ (2006). Even though above-median debtors face an additional hurdle to filing, they must pass the so-called "means test" which permits a Chapter 7 filing only if their disposable income is below specified caps. However, only around $8 \%$ of Chapter 7 filers have incomes above the state median.

303 Elisa Brodi \& Giacomo Rodano, Debt Discharge \& Credit 12 (Preliminary Draft, Sept. 2013, on file with author) (discussing the "scant" evidence regarding the relationship of debt relief and credit cost, and reporting results of an empirical study indicating no increase cost of credit where discharge is available). 
will likely not be sufficient to satisfy all of the human rights concerns raised here. For example, requiring the debtor to exist on subsistence level income indefinitely - diverting all benefits of the labor to creditors indefinitely - may infringe upon the debtor's human dignity, even if the state provides food and shelter. Moreover, privacy and anti-discrimination principles must still be met. A nation that provides adequate food and housing, yet still permits creditors to invade debtors' dwellings and permits employers to discriminate would nonetheless be incompliant with human rights concerns.

\subsubsection{Limitations on Consumer Credit Contracts}

Nations that carefully regulate consumer credit contracts ex ante may be less likely to have an over-indebtedness problem or may be less likely to permit easy discharge of consumer credit obligations. Until recently, Italy did not have a mechanism for individuals to discharge their consumer debt, ${ }^{304}$ but nevertheless Italy sharply limits usury and provides harsh penalties for usury violations. ${ }^{305}$ Some nations simply do not have many overindebted individuals because they do not have a robust consumer lending apparatus. ${ }^{306}$ In such economies, illegal and unregulated lending may occur. These may have human rights obligations with respect to such lending (in particular where debtors' lives or wellbeing are threatened by nefarious collection methods, particularly in the case of loan sharks), but an insolvency regime may not be an effective method of meeting these obligations. In other economies, low levels of consumer lending may be a policy choice, or extremely robust consumer protection laws may sharply limit the number of individuals who become over-indebted. ${ }^{307}$

It may be the case that if a nation does not have an overindebtedness problem, an insolvency regime will not be necessary to comply with its human rights obligations related to over-

304 Business debt, however, was previously dischargable pursuant to the 2005-2006 Bankruptcy Reform. Decreto Legge 16 marzo 1942, n. 267 (It.) (amended 2006, 2007 and 2009) [Decree Law of Mar. 16, 1942].

305 London Economics Report, supra note 5, at 62-63.

306 World Bank Report, supra note 1, at 8.

307 World Bank Report, supra note 1, at 9. 
indebtedness. ${ }^{308}$ On the other hand, even if over-indebtedness is not an epidemic in a given country, that does not mean that there are not over-indebted individuals who may be in need of protection and whose human rights may be compromised by their debt situation or the attendant collection activities. Even if consumer credit is not a serious concern, there may be other incidences of indebtedness, such as medical debt, resulting in overindebted individuals and implicating human rights principles. To the extent that over-indebtedness is due to medical debt, measures may be needed to address related human rights concerns even if consumer credit contracts are carefully circumscribed.

While nations that do not have a high level of consumer debt or that limit the types of consumer debt that can exist may not need a robust debt relief regime, nations whose economies rely heavily on consumer credit - and nations that permit particularly onerous consumer credit contracts - are more likely to require meaningful redress for over-indebtedness that takes into account human rights concerns. An insolvency regime may be one way of mitigating the consequences of "high-risk, high-profit" lending which is both more likely to trigger economic human rights infractions (as well as more likely to generate systemic risk concerns). ${ }^{309}$ Payday loans and other subprime loans are particularly likely to cause debtors to become trapped in a "never-ending debt spiral" that interferes with their ability to meet their basic economic needs. ${ }^{310}$

Not only will the nature of credit contracts that are permitted to exist determine the type of relief necessary to protect debtors' rights to adequate living and dignity, but the nature of these contracts will also determine what is required in terms of property and due process rights, as discussed above. The default legal regime will determine the scope of debtors' and creditors' property and due process rights. Any response to over-indebtedness or insolvency regime will need to protect the property rights it has allowed to come into existence through consumer credit contracts and will need to provide appropriate process to protect the

308 That is not to say that all human rights obligations will be satisfied; other action may of course be needed to address poverty concerns or other problems separate from the issue of over-indebtedness.

309 World Bank Report, supra note 1, at 31.

310 World Bank Report, supra note 1, at 32; Nathalie Martin, 1,000\% Interest Good While Supplies Last: A Study of Payday Loan Practices and Solutions, 52 ARIz. L. REV. 563, 564 (2010). 
contractual and property rights that have been promised.

\subsubsection{Default Collection Remedies}

If a nation sharply circumscribes creditors' collection remedies, an insolvency regime devoted to discharging or reorganizing the debtors' obligations may not be needed. For example, if a nation exempts the debtor's home and most of the debtor's wages from collection and otherwise prohibits creditor harassment, an official insolvency regime may not be required for a nation to comply with basic human rights obligations relating to debt relief. ${ }^{311}$ Nations can prohibit lenders from invading debtors' privacy and can also prohibit lender discrimination. However, if insufficient exemptions or restrictions are in place - or if creditors routinely ignore such prohibitions - the nation may need an official insolvency process to free debtors to meet their basic needs and avoid creditor harassment.

The Council of Europe's Recommendation acknowledged that limitations on collection activity may be needed to comply with human rights obligations, stating:

Over-indebtedness may have a strongly adverse impact on the development of children in over-indebted families. It may not only reduce the capacity of adult members of the family to re-engage in an income-generating activity but, inter alia, can also prevent or substantially limit the same capacity for their children. Therefore, debt recovery procedures should protect the essential assets of the debtor by means of, for instance, garnishment of a part of income to ensure that a fair balance is struck between the basic living needs of the debtor and his or her family and the efficiency of debt repayment. ${ }^{312}$

It is again important to keep in mind, however, that restrictions on collection activities may not resolve all human rights concerns related to over-indebtedness, just as a robust social safety net may be insufficient. Restricting aggressive and invasive collection practices may resolve many privacy and discrimination concerns;

\footnotetext{
311 World Bank Report, supra note 1, at 9.

312 Council of Europe Recommendation, supra note 10, at 15.
} 
however, other parties (such as employers) may also need regulation against discrimination and privacy invasions pertaining to over-indebtedness. In addition, some individuals may be severely over-indebted, and they may lack access to adequate housing and food, and/or their human dignity may be imperiled even if creditor collection activity is very carefully circumscribed. Examination of each human rights principle is necessary to form a full picture of the needs of debtors and the human rights risks that over-indebtedness creates, and also provides an opportunity for a comprehensive response to the human rights issues this analysis brings to light.

\subsection{Barriers and Alternatives to Insolvency Regimes}

Although some response to over-indebtedness seems necessary from a human rights perspective, an insolvency regime may not be feasible or may not be the most desirable way of meeting these obligations. First, in nations where judicial processes are corrupt or otherwise problematic, or where the public does not accept or rely on the legal system, an insolvency regime may not be the optimal or exclusive solution for satisfying human rights principles. $^{313}$ In other cases, societies may not view indebtedness as a burden that falls on the individual, but may treat indebtedness as a matter to be resolved by the debtor's family, tribe, or some other social group to which the debtor pertains. ${ }^{314}$

Even if over-indebtedness triggers human rights concerns, an insolvency regime is not the only possible response, and the nature of the insolvency regime can vary and still comply with the human rights principles discussed here. Some jurisdictions prefer voluntary settlement to a formal debt relief procedure, citing benefits including reduced stigma, reduced court cost, flexibility, and political expedience. ${ }^{315}$ However, if a voluntary settlement regime is the method for responding to human rights concerns, it must be accessible and effective, as discussed below. ${ }^{316}$ So far, in practice successful voluntary settlements have seldom been

\footnotetext{
313 World Bank Report, supra note 1, at 8.

314 World Bank Report, supra note 1, at 8 .

315 World Bank Report, supra note 1, at 46.

316 See infra Part X.
} 
achieved, particularly absent some type of institutional support. ${ }^{317}$ In some jurisdictions, voluntary settlement opportunities have been co-opted by questionable for-profit entities seeking to extract some value from over-indebted individuals, sometimes taking advantage of desperation and lack of understanding. ${ }^{318}$ If voluntary settlement is to represent a meaningful opportunity for rehabilitation, there must be some mechanism for halting enforcement actions while negotiations are ongoing, debtors must have access to meaningful guidance in the process, and there must be appropriate oversight to ensure creditor participation in good faith, including limits on the ability of dissenting creditors to derail the agreements. 319

\subsection{The "Effectiveness" of Responses to Over-Indebtedness}

If evaluation of the default response to over-indebtedness (that is, the fate of over-indebted individuals absent an insolvency regime) reveals that such individuals are exposed to human rights violations, nations may wish or may be required to provide debtors with an opportunity to alleviate their indebted condition and the available remedy should be accessible and effective. This section focuses on some of the barriers to access to insolvency regimes that may make insolvency relief an ineffective remedy.

Human rights instruments typically provide for "effective" remedy or recourse for the redress of violations of the protected human rights. The ACHR provides for "simple and prompt recourse, or any other effective recourse, to a competent court or tribunal for protection against acts that violate his fundamental rights ...." 320 Signatories also agree to ensure the enforcement of

317 World Bank Report, supra note 1, at 46-48.

318 See, e.g., What's the Difference Between a Credit Counselor and a Debt Settlement Company?, CONSUMER FIN. PROT. BUREAU, http://www.consumerfinance.gov/askcfpb/1449/whats-difference-betweencredit-counselor-and-debt-settlement-company.html (last updated June 18, 2014) (explaining that debt settlement agencies are for-profit companies and often do not achieve better terms for debtors than debtors can achieve on their own, and that filing for bankruptcy is often a better option).

319 World Bank Report, supra note 1, at 48-49.

320 American Convention, supra note 93, art. 25. 
remedies granted. ${ }^{321}$ The ECHR requires "an effective remedy before a national authority" for those whose Convention rights have been violated. ${ }^{322}$ Signatories to the ICCPR also agree to "adopt such laws or other measures as may be necessary to give effect" to Covenant rights and to provide for an "effective remedy" for the violation of the rights. 323 Thus, if in reviewing the situation of over-indebtedness, a nation elects to use an insolvency regime to meet some of its human rights obligations, relief must be accessible. The ICESCR does not contain a provision requiring effective remedies, but rather requires states to pursue the "progressive realization" of the rights described. States wishing to incorporate human rights concerns raised in the ICESCR may nevertheless be interested in assuring that the aspired remedies are indeed effective.

The World Bank noted that barriers to insolvency relief can have deleterious consequences for debtors: "[h]igh access barriers to the formal system of relief may result in individuals being in a state of "informal insolvency" in which they "lose incentives to participate in society, may require continuing state support, or may go 'underground' for several years to avoid creditors . . ." 324 Creditor collection, the Report's drafters noted, brings little to creditors but "inflicts a significant social and emotional toll." 325

In some jurisdictions, including the United States, cost represents a significant barrier to access. ${ }^{326}$ Countries employ a variety of approaches for financing debtor access to their insolvency system, including: 1) direct state funding of both debtor and creditor costs, 2) funding from higher asset bankruptcies subsidizes low or no asset bankruptcies, 3) state funding for professionals, 4) funding from levies on creditors, and 5) no state support. 327

321 American Convention, supra note 93, art. 25, § 2.

322 Convention for the Protection of Human Rights and Fundamental Freedoms, supra note 101, art. 13.

323 ICCPR, supra note 62 , art. 2, §§ 2, 3 .

324 World Bank Report, supra note 1, at 65.

325 Id.

326 Angela Littwin, The Affordability Paradox: How Consumer Bankruptcy's Greatest Weakness May Account for its Surprising Success, 52 WM. \& MARY L. REV. 1933, 1957-59 (2011); Liz Weston, When You're Too Poor for Bankruptcy, MSN MONEY (Aug. 20, 2012, 2:15 PM), http://money.msn.com/credit-rating/whenyoure-too-poor-for-bankruptcy-liz-weston.

327 World Bank Report, supra note 1, at 61. 
Some barriers to access are not financial but rather are procedural. Some jurisdictions provide relatively open access 328 to debt relief in insolvency proceedings, while others sharply limit entry into the system. Some jurisdictions only permit debt relief for debtors who show "permanent insolvency," or a showing that indebtedness is due to an event beyond the debtor's control; other jurisdictions require a showing of good faith. ${ }^{329}$ Where nations have erected such barriers designed (purportedly) to limit access to debtors who could afford to repay their debts, such barriers have often in practice restricted access for precisely those debtors whose economic human rights are most imperiled by their over-indebted situation.

The United States is one jurisdiction in which debt relief in bankruptcy is likely necessary from a human rights perspective, yet there are both legal and cultural barriers to effective relief. In 2005, Congress erected substantial barriers to debt relief. Debtors in need of relief could no longer access bankruptcy immediately in many cases. Debtors are first required to obtain counseling and gather a number of documents, including tax returns and pay stubs. 330 These barriers hit the poorest debtors hardest, as many of the new requirements resulted in raising the cost of bankruptcy. ${ }^{331}$ As discussed above in analyzing the anti-discrimination requirements, debt discharge is not available to all debtors equally; debtors in certain jurisdictions and non-white debtors are much less likely to obtain a discharge. 332

Insolvency relief is also arguably not accessible if accessing the regime involves stigmatization or other deleterious consequences. For example, in Austria debt cancellation is only available if the debtor agrees to inform future employers of the insolvency. As a result, few debtors choose the debt cancellation option and instead enter some kind of voluntary repayment plan. The employer notification requirement may constitute a de facto bar to debt relief

328 World Bank Report, supra note 1, at 64 (defining "open access" systems as those in which "an individual who meets an insolvency test such as the inability to pay debts as they fall due may, without more, gain access to an insolvency procedure permitting an ultimate discharge of debts").

329 World Bank Report, supra note 1, at 64.

33011 U.S.C. $\S 521$ (2012).

331 Jon Chavez, At 8, Insolvency Reform Act Falls Short of Goals, THE BLADE (Oct. 5, 2013), http://www.toledoblade.com/Economy/2013/10/06/ At-8insolvency-reform-act-falls-short-of-goals.html.

332 See supra Part IV.C. 
in many cases. 333

If a country is relying on its exemption laws to protect against human rights violations rather than on an insolvency regime, the exemption laws must also be an effective remedy. In many states, exemptions are not automatic but debtor must file papers and attend hearings ${ }^{334}$ - debtors must be sufficiently informed and the process for claiming exemptions must be easily navigable and affordable. If states rely on anti-garnishment laws to preserve debtors' dignity and ability to meet their basic needs, banks should be required to verify that the funds are not exempt before executing garnishment orders. ${ }^{335}$ In the U.S., banks are required to verify that the bank account does not contain federal benefits before executing a garnishment order, but most states do not require banks to verify that the funds are not exempt wages or state benefits. ${ }^{336}$ Absent such protection, the cascading harms can seriously impair debtors' human rights. For instance, an improper garnishment of $\$ 500$ worth of Social Security Benefits caused an Illinois couple to miss a payment on their mortgage, triggering foreclosure proceedings. 337

\section{CONCLUSION}

This paper endeavored to provide a preliminary guide for those policymakers that are either obliged to or desire to craft responses to over-indebtedness with cognizance of human rights principles. I suggested that this analysis will be different for each jurisdiction. The nature of the response to over-indebtedness, including whether and what nature of debt relief regime is required, depends upon both the background legal and regulatory regime and also upon cultural factors. Specifically, nations with more robust social safety nets may not need to provide prompt discharge of debt for each debtor to satisfy obligations of adequate

333 London Economics Report, supra note 5, at 15-16.

334 Carter \& Hobbs, supra note 144, at 8.

335 See Carter \& Hobbs, supra note 142, at 23-25 (describing state laws that allow creditors to clean out a debtor's bank account completely).

336 Carter \& Hobbs, supra note 142, at 25 (citing 31 C.F.R. Part 444) (explaining that treasury regulation requires banks to verify that funds garnished are not federal benefits).

337 Carter \& Hobbs, supra note 142, at 7. 
food and housing, for example, although their responses to overindebtedness will still need to account for other human right concerns. Additionally, privacy protections and bans on discrimination in creditor practices may satisfy, at least partially, human rights concerns relating to debt collection. Nations will also have varying needs for debt relief depending on other restrictions placed on consumer credit contracts. If nations choose to use insolvency regimes to address human rights obligations, they will need to ensure that the relief is accessible and thus effective. On the other hand, there may be other reasons that an insolvency regime will not be an effective method of satisfying human rights obligations, such as insufficient legal infrastructure or a cultural preference for resolving debt obligations communally outside of official debt relief proceedings.

Although this paper did not stake a normative position on the need for incorporating human rights principles in responses to over-indebtedness, it illustrated that in many cases, particularly in the U.S., current responses to over-indebtedness do not fully satisfy human rights principles. As discussed in much greater detail in Part IV, to comply with human rights principles, the U.S. would need, among other reforms, greater protection against abusive debt collection practices, greater protection of debtors' adequate living standards, and debt relief that is equally available to all.

Although this paper does not argue that a human rights framework is required in responding to over-indebtedness, I will identify some benefits to a debt relief system that takes into account human rights concerns. First, a robust, equitable, accessible insolvency regime may aid a nation in fulfilling its obligation to meet human rights goals, such as providing for its non-debtor residents' essential needs for food, housing and healthcare. It is costly to offer a welfare system that ensures that all residents have access to food, housing, and medical care. Some over-indebted individuals may not need to tap the social welfare system in order to meet their needs - they may need only to reduce their debt loads in order to have disposable income sufficient to satisfy these needs. In other words, creditors rather than taxpayers can bear some of the cost of restoring such individuals to a level of basic health and safety. ${ }^{338}$ Creditors can bear more of the burden

338 World Bank Report, supra note 1, at 36: "Individuals trapped in an endless debt cycle consumer previous social benefits, especially but not 
for debtors whose income shortfalls have been caused primarily by over-indebtedness, and government funds can be freed to satisfy the obligations of impoverished individuals for whom debt relief is no help. ${ }^{339}$ Nations that have undertaken human rights obligations to provide residents with access to food, housing, and healthcare may wish to use their insolvency regime to defray the cost of meeting such obligations, particularly where their ability to provide a robust social safety net has been curtailed by the economic downturn. Importantly, governments must also realize that failing to provide an adequate social safety net, particularly in the healthcare and housing contexts, can be the direct cause of over-indebtedness that imperils debtors' human rights obligations.

Second, a robust, equitable, and accessible insolvency regime may be one tool for responding to systemic risk concerns. For example, had U.S. lawmakers considered seriously the rights to privacy, adequate housing, and dignity, they may have permitted modification of mortgage lenders' claims in bankruptcy, which in turn may have mitigated the effects of the housing crisis. ${ }^{340}$ Insolvency regimes that take into account human rights concerns are more likely to be impactful from an economic standpoint. This is because debtors should be able to adjust and reintegrate into the economy more readily if the available debt relief, in conjunction with any relief the state makes available outside the insolvency

exclusively in states that provide some measure of social support (welfare)." These include unemployment benefits, food stamps, health benefits, and child allowances. Of course, impoverished individuals who do not carry debt loads, or for whom debt relief is not a long-term solution given lack of income, will not benefit from a robust insolvency regime. The cost of rehabilitating these individuals must be born by the government rather than creditors; such individuals will require relief from the public social safety net in order to meet their basic needs.

339 World Bank Report, supra note 1, at 12.

[F]ar from every overburdened debtor faces social exclusion and utter destitution. Lack of resources to meet basic needs may well lead to problems managing debt, but these problems do not always appear together .... An insolvency regime serves mainly individuals who do not suffer from a long-term disability or general surfeit of resources and who thus do not need affirmative social support. Insolvency regimes are designed primarily and work best for individuals who are not capable of producing sufficient income to support themselves and their families, but an overwhelming debt burden saps their initiative and depresses their productive capacity.

Id. at 11-12.

340 Levitin, supra note 33, at 585. 
system, enables the debtor to access adequate food, housing, and healthcare, protects dignity, privacy, and property, and is equitable and accessible. A human rights lens also promotes economic stability by amply protecting creditors' rights to property and due process.

In a subsequent paper, I argue that a human rights framework is a beneficial lens for debtor-creditor relationships. If this argument is persuasive, there is much more work to be done: each of the human rights discussed here play a role in many aspects of consumer credit, from the regulatory regime, to the creation of consumer credit relationships, to every facet of enforcement and resolution of these contracts. For example, the right to education has implications for the resolution of student debt, particularly in the United States where many students are unable to receive an education without undertaking crippling debt obligations. ${ }^{341}$ As the flow of credit becomes increasingly international, as individual consumers increasingly cross borders, and as creditors increasingly operate internationally, it is only sensible to apply the best tools available for establishing minimal obligations of justice - and human rights continues to be the best framework available for such a task.

\footnotetext{
341 See, e.g., Meta Brown, Student Debt Overview: Postsecondary National Policy Institute (PNPI) 8/14/13, FED. RESERVE BANK OF N.Y., available at http://www.newyorkfed.org/regional/Brown_presentation_GWU_2013Q2.pdf (describing "aggregate student debt balances approaching $\$ 1$ trillion"); Peter Coy, Student Loans: Debt for Life, BlOOMBERG BUS. WEeK (Sept. 18, 2012), http://www.businessweek.com/articles/2012-09-06/student-loans-debt-for-life ("[E]stimat[ing] that student debt, compounded by rising enrollments, is growing by nearly $\$ 3,000$ a second.").
} 